\title{
Accesibilidad para personas con baja visión de los gráficos estadísticos en la prensa digital: una propuesta metodológica basada en indicadores heurísticos
}

\author{
Accessibility for people with low vision of statistical \\ graphics in the digital press: A methodological proposal \\ based on heuristic indicators
}

\author{
Rubén Alcaraz-Martínez; Mireia Ribera-Turró; Toni Granollers-Saltiveri; Afra Pascual
}

Cómo citar este artículo:

Alcaraz-Martínez, Rubén; Ribera-Turró, Mireia; Granollers-Saltiveri, Toni; Pascual, Afra (2020). “Accesibilidad para personas con baja visión de los gráficos estadísticos en la prensa digital: una propuesta metodológica basada en indicadores heurísticos". Profesional de la información, v. 29, n. 5, e290515.

https://doi.org/10.3145/epi.2020.sep.15

Artículo recibido el 10-01-2020

Aceptación definitiva: 01-04-2020
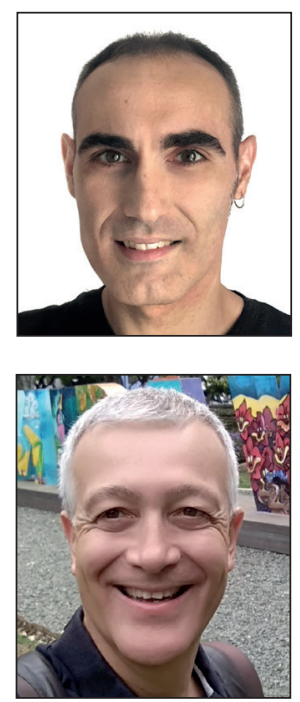

\author{
Rubén Alcaraz-Martínez \\ https://orcid.org/0000-0002-7185-0227 \\ Universitat de Barcelona. \\ Departament de Biblioteconomia, \\ Documentació i Comunicació Audiovisual \\ Melcior de Palau, 140 \\ 08014 Barcelona, España \\ ralcaraz@ub.edu
}

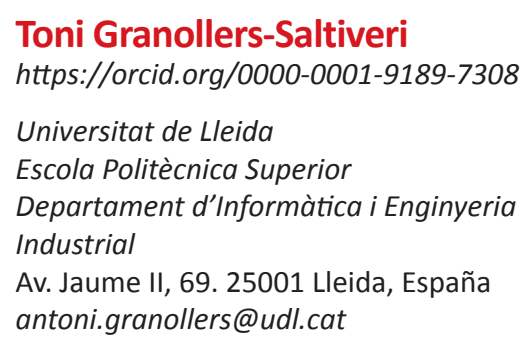

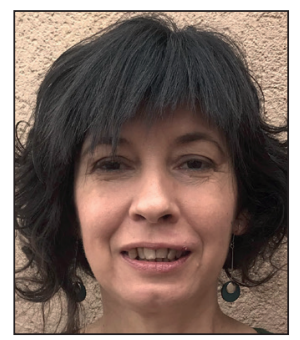

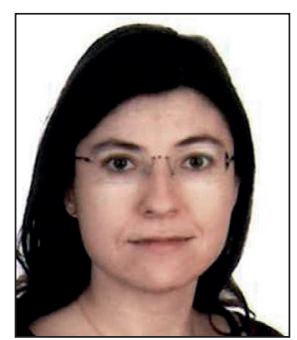

Mireia Ribera-Turró

https://orcid.org/0000-0003-1455-1869

Universitat de Barcelona

Departament de Matemàtiques i

Informàtica

Gran Via de les Corts Catalanes, 585

08007 Barcelona, España

ribera@ub.edu

Afra Pascual

https://orcid.org/0000-0002-2368-755X

Universitat de Lleida

Escola Politècnica Superior

Departament d'Informàtica i Enginyeria Industrial

Jaume II, 69. 25001 Lleida, España

apascual@diei.udl.cat

\section{Resumen}

Se presenta un nuevo conjunto de indicadores heurísticos para la evaluación de la accesibilidad de los gráficos estadísticos para personas con baja visión y visión cromática deficiente (VCD), así como un método para su aplicación. Con el objetivo de validar la propuesta, se ha realizado una evaluación heurística de la accesibilidad de 35 gráficos publicados en 5 diarios españoles y 2 internacionales. Los resultados muestran que los indicadores propuestos consiguen detectar una mayor cantidad de problemas únicos, presentan una mejor distribución de los problemas entre heurísticos y consiguen detectar problemas más severos y específicos que las Web content accessibility guidelines (WCAG). En relación con los problemas detectados, destaca la prácticamente nula presencia de alternativas textuales en los gráficos publicados como imágenes en formato de mapa de bits, un problema que también se da en el caso de los gráficos publicados en formato SVG, donde destaca el nulo etiquetado de las marcas con estándares como WAI-ARIA. En estos últimos también se observa el pobre uso de indicadores para remarcar los elementos que reciben el foco, o su inaccesibilidad mediante una interfaz de teclado. Otros problemas comunes en ambos tipos de gráficos son la ratio de contraste entre elementos no textuales, por debajo en muchos casos del mínimo requerido, un tamaño de fuente demasiado pequeño o la no sistematización del uso de paletas de colores seguras para personas con VCD. Por lo que respecta a la comparación entre medios nacionales e internacionales, si bien las puntuaciones obtenidas por los internacionales son superiores, éstos comparten 
un importante número de problemas con los españoles. La lista de indicadores obtenida, más allá de demostrarse útil para propósitos evaluativos, también lo hace como guía para la creación de gráficos accesibles fácilmente incorporable a las guías de estilo de los medios analizados.

\title{
Palabras clave
}

Gráficos estadísticos; Visualización de la información; Baja visión; Visión cromática deficiente; Ceguera al color; Daltonismo; Accesibilidad web; Prensa digital; Prensa online; Evaluación heurística; Guías de estilo.

\begin{abstract}
A new set of heuristic indicators is presented for the evaluation of the accessibility of statistical charts for people with impaired vision and color vision deficiency (CVD), as well as a methodology for their application. To validate the proposal, a heuristic evaluation of the accessibility of 35 charts published in 5 Spanish and 2 international newspapers is carried out. The results show that the proposed indicators enable the detection of a greater number of unique problems, present a better distribution of problems among heuristics, and enable the detection of more severe and specific problems compared with the Web content accessibility guidelines (WCAG). Regarding the problems detected, the lack of text alternatives to charts in bitmap format stands out, a problem that also occurs in the case of charts in SVG format, for which standards such as WAI-ARIA are not used for labeling the marks. The latter also underlines the poor use of indicators to highlight the elements that receive focus, or their inaccessibility through a keyboard interface. Other common problems with both types of charts are the non-text contrast ratio, which in many cases is below the minimum required, too small a font size, or the non-systematization of the use of color palettes appropriate for people with CVD. The comparison between national and international media reveals that, although higher scores are obtained by international media, they share a significant number of the problems identified for Spanish media. The list of principles obtained, beyond proving helpful for evaluative purposes, is also useful as a guide for creating accessible charts that could be easily incorporated into the style guides of the analyzed media.
\end{abstract}

\section{Keywords}

Statistical charts; Information visualization; Low vision; Color vision deficiency; Color blindness; Daltonism; Web accessibility; Digital press; Online press; Heuristic evaluation; Style guides.

\section{Financiación}

Estre trabajo ha sido realizado en el marco del programa de doctorado Ingeniería y Tecnologías de la Información de la Universitat de Lleida. Está parcialmente financiado por el proyecto español PID2019-105093GB-I00 (Mineco/ Feder, UE), el programa Cerca de la Generalitat de Catalunya, y el programa Retos del Ministerio de Ciencia, Innovación y Universidades RTI2018-095232-B-C21 y SGR 1742.

\section{Introducción}

En las últimas dos décadas se ha observado una creciente presencia de los medios de comunicación en la Red y, en concreto, de la prensa escrita, una cuestión que ha llevado a diversos autores y entidades a realizar trabajos orientados a evaluar la usabilidad y accesibilidad de la prensa digital (Discapnet, 2007; Parra-Valcarce, 2010; Roa-Amaya; Caldera-Serrano, 2011; Cabañero-Resta; Luján-Mora, 2012; Discapnet, 2016; González-Perea, 2018; Parra-Valcarce; Martínez-Arias, 2018), los medios de comunicación audiovisuales (Utray, 2009), así como a proponer pautas y criterios para la creación de contenido audiovisual accesible en la Web (Gutiérrez-Restrepo, 2015). No obstante, ningún trabajo hasta el momento se ha centrado en el análisis de la accesibilidad de los gráficos estadísticos presentes en estos medios, limitándose los estudios existentes a evaluar de manera genérica la presencia de alternativas textuales para el contenido no textual, como criterio incluido en las Web content accessibility guidelines (WCAG) del World Wide Web Consortium (2018a).

En el caso particular de los gráficos estadísticos, la bibliografía científica se ha centrado en estudiar su accesibilidad para las personas ciegas o con muy poco resto de visión. Fundamentalmente, se han propuesto cuatro aproximaciones en vistas a mejorar su accesibilidad:

- el uso de alternativas textuales,

- la generación de alternativas táctiles,

- la implementación de esquemas sonoros, y

- la creación de presentaciones multimodales (Alcaraz-Martínez et al., 2020).

Si bien estas aproximaciones pueden ser útiles para las personas ciegas e incluso para los usuarios con baja visión severa, al centrarse en alternativas diferentes a la gráfica como tablas de datos estructurados, resúmenes o el uso de sonidos para comunicar tendencias, no presentan la misma capacidad para mostrar de una manera eficiente tendencias o comparativas entre variables. Esto implica además un mayor uso de la memoria a corto plazo y una superior carga cognitiva cuando se busca obtener respuestas o conclusiones a partir de datos tabulados. No debemos olvidar que un importante 
porcentaje de usuarios con baja visión todavía conserva un resto de visión suficiente para visualizar los gráficos, ya sea simplemente ampliándolos, o gracias al soporte de ayudas técnicas como los magnificadores de pantalla, y que estas personas prefieren usar ese resto visual en su día a día (Szpiro et al., 2016), condición que las alternativas mencionadas no explotan. En la figura 1, se puede observar un ejemplo de la diferencia entre la lectura de los mismos datos representados en forma de tabla y gráfico.

\begin{tabular}{|l|c|c|c|c|c|c|c|c|c|c|c|c|}
\cline { 2 - 13 } \multicolumn{1}{c|}{} & Ene & Feb & Mar & Abr & May & Jun & Jul & Ago & Sep & Oct & Nov & Dic \\
\hline $\mathbf{2 0 1 3}$ & 17.589 & 24.156 & 27.165 & 29.541 & 32.146 & 24.563 & 14.743 & 16.230 & 15.636 & 19.999 & 31.545 & 18.354 \\
\hline $\mathbf{2 0 1 4}$ & 22.895 & 26.746 & 32.565 & 31.050 & 35.241 & 26.124 & 16.923 & 17.028 & 22.712 & 27.351 & 26.558 & 16.607 \\
\hline $\mathbf{2 0 1 5}$ & 18.729 & 23.027 & 26.966 & 25.407 & 28.548 & 25.197 & 19.885 & 18.207 & 28.065 & 32.033 & 30.104 & 18.817 \\
\hline
\end{tabular}

Visitas al sitio web entre 2013 y 2015

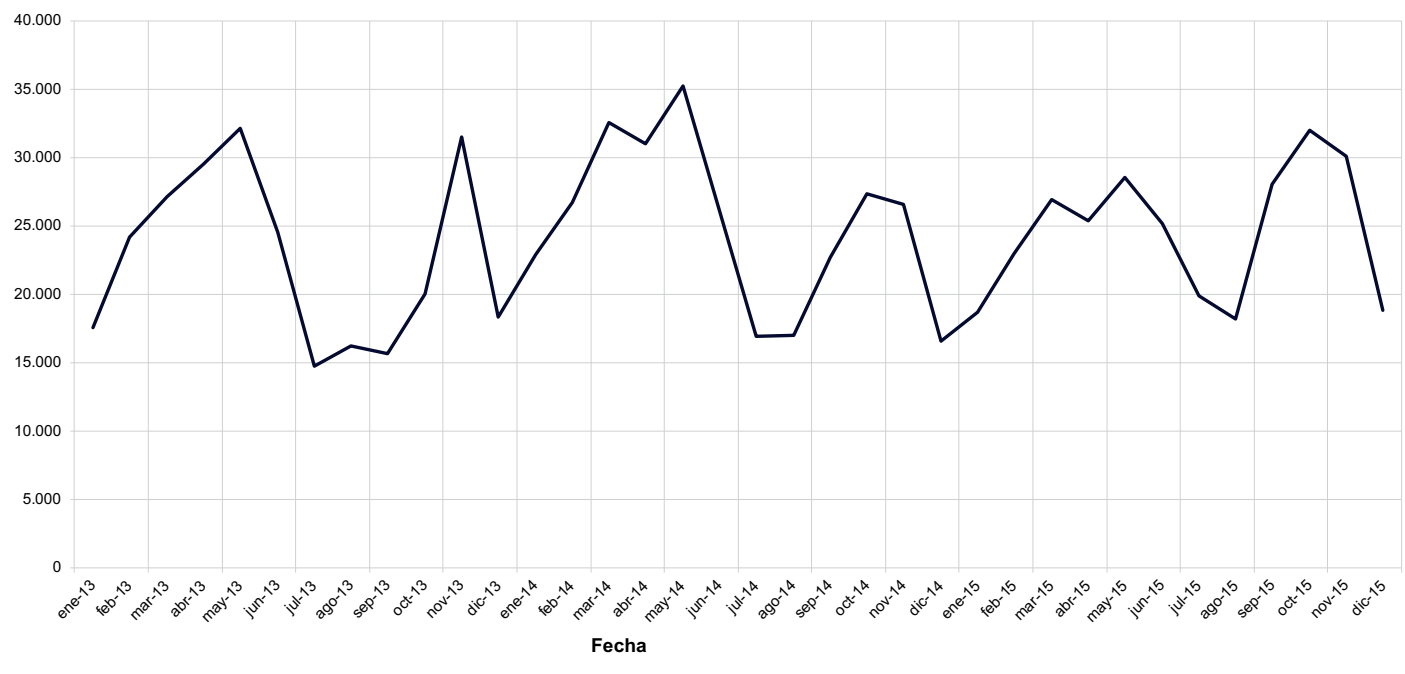

Figura 1. Comparación entre una representación tabular y una representación gráfica de los mismos datos. Mediante la versión gráfica es posible observar rápidamente tendencias, cosa que en la tabla requiere un tiempo superior

Los gráficos estadísticos están presentes en todos los sectores clave de la sociedad. En el ámbito educativo, el currículo básico regulado por ley en España (2014; 2015), recoge la necesidad de que los estudiantes sean capaces de interpretar y crear diferentes tipos de gráficos estadísticos en distintas materias y niveles formativos. En el ámbito científico, la representación gráfica acostumbra a ser una de las principales formas a través de las cuales se comunican los resultados de investigación. En el caso de los medios de comunicación, la prensa siempre se ha valido de gráficos para representar datos y estadísticas. El movimiento de datos abiertos y la puesta a disposición de grandes conjuntos de datos en acceso abierto no ha hecho más que potenciar el denominado periodismo de datos, multiplicando este tipo de representaciones gráficas en los medios de comunicación y aumentando su interés entre periodistas, académicos, informáticos y diseñadores (Meeks; Cesal; Pettit, 2019). La inteligencia de negocios es también otra área en la que los gráficos estadísticos sirven para la exploración, análisis y comunicación (Cairo, 2017). Estos son sólo cuatro ejemplos de sectores clave de la sociedad que justifican la necesidad de contar con gráficos accesibles para garantizar el acceso a la información y el conocimiento de las personas con discapacidad.

Según datos de la Organización Mundial de la Salud (World Health Organization, 2019), alrededor de 1.300 millones de personas en el mundo presentan algún tipo de discapacidad visual, de las cuales el 95\% presentan algún tipo de baja visión. La prevalencia a nivel mundial, tomando como referencia los datos de población del último informe demográfico de la División de Población de las Naciones Unidas (2017), es de alrededor del 17,1\%. Una cifra en crecimiento debido a diversos factores como el aumento de la tasa de enfermedades como la diabetes, pero, principalmente, como consecuencia del envejecimiento global de la población (Miqueli-Rodríguez; López-Hernández; Rodríguez-Masó, 2016). Sin ir más lejos, aproximadamente el $86 \%$ de las personas ciegas, el $80 \%$ de las personas con baja visión moderada y grave, el $74 \%$ de las personas con baja visión leve y el 61\% de la población mundial con presbicia tienen 50 años o más (Bourne, 2017).

Se considera que una persona presenta baja visión cuando con la mejor corrección óptica posible, su agudeza visual es inferior a 20/60, o su campo de visión es inferior a 20 grados (Legge, 2016). Una agudeza visual "normal" es la de las personas que obtienen un resultado de 20/20 en el test de Snellen (1862) y su campo visual es de 90 grados a ambos lados y 50 grados por encima y 60 por debajo de la nariz (Legge, 2016). Esto implica que dentro de este

\section{Los gráficos estadísticos están presentes} en todos los sectores clave de nuestra sociedad 
perfil de usuario podemos encontrar tanto a personas con una agudeza visual que va desde el reconocimiento de la forma de una mano, hasta un 2/60 en el test Snellen, combinado o no con un campo visual de menos de 5 grados (B2 en la clasificación IBSA), como a personas con un resto de visión situado entre $2 / 60$ y $6 / 60$ en el mismo test y/o un campo visual de entre 5 y 20 grados (B3 en la clasificación IBSA) (IBSA, 2011). También a personas con problemas no sólo relacionados con la agudeza visual o el campo de visión (figura 2), sino también con la sensibilidad a la luz, al contraste (figura 3) -no sólo entre texto o imagen respecto al fondo, sino también entre elementos adyacentes- (figura 3), o con dificultad o imposibilidad para diferenciar colores (conocida como visión cromática deficiente, en adelante VCD) (figura 4). En este sentido, la gran variabilidad presente en este perfil de usuario implica grandes diferencias en las capacidades entre dos personas con baja visión, así como en las estrategias, preferencias y ayudas técnicas (lectores de pantalla, magnificadores, opciones de contraste, etc.) utilizadas para acceder al contenido disponible en las webs.

Ante la inexistencia de principios específicos para evaluar la accesibilidad para personas con baja visión de los gráficos estadísticos disponibles en la Web, se ha creado un nuevo método basado en heurísticas. Las evaluaciones heurísticas son métodos de inspección de una o varias dimensiones clave de una interfaz (González; Pascual; Lorés, 2001). En este tipo de revisiones, muy extendidas en el ámbito de la usabilidad y la accesibilidad, varios expertos se valen de su experiencia y se basan en su propio juicio para examinar la interfaz en base a una serie de principios denominados indicadores heurísticos. Esta técnica tiene su origen en el trabajo seminal de Nielsen y Molich (1990), base sobre la cual otros autores han realizado propuestas metodológicas para la confección de nuevas listas de heurísticas para la evaluación tanto de aspectos generales relacionados con la usabilidad, la accesibilidad o la experiencia de usuario, como con aspectos más específicos de las interfaces o de tipos concretos de sitios o aplicaciones web, conocidas como "heurísticas de dominio" (Hub; Čapková, 2010; Rusu et al., 2011; Van Greunen et al., 2011; Masip; Oliva; Granollers, 2012; Lechner et al., 2013; Franklin et al., 2014; Hermawati; Lawson, 2015; Jiménez et al., 2017; Quiñones et al., 2018).

Frente a la posibilidad de recopilar y presentar una guía de buenas prácticas para la creación de gráficos estadísticos accesibles, se ha optado por la creación de un conjunto de indicadores heurísticos. Estos indicadores se pueden utilizar tanto para la evaluación, como para la posterior creación de guías específicas, con el objetivo de dar a conocer los requisitos de accesibilidad aplicables entre autores y diseñadores. El presente trabajo busca pues dos objetivos. En primer lugar, conocer el grado de adecuación de los gráficos estadísticos presentes en la prensa digital a las características de accesibilidad requeridas por parte de las personas con baja visión o VCD, a partir de una muestra extraída de los medios de máxima difusión. En segundo lugar, se pretende validar la propuesta de indicadores heurísticos en términos de eficacia, con el objetivo de obtener un conjunto de indicadores que sirva tanto para la evaluación, como para la elaboración de guías de buenas prácticas.

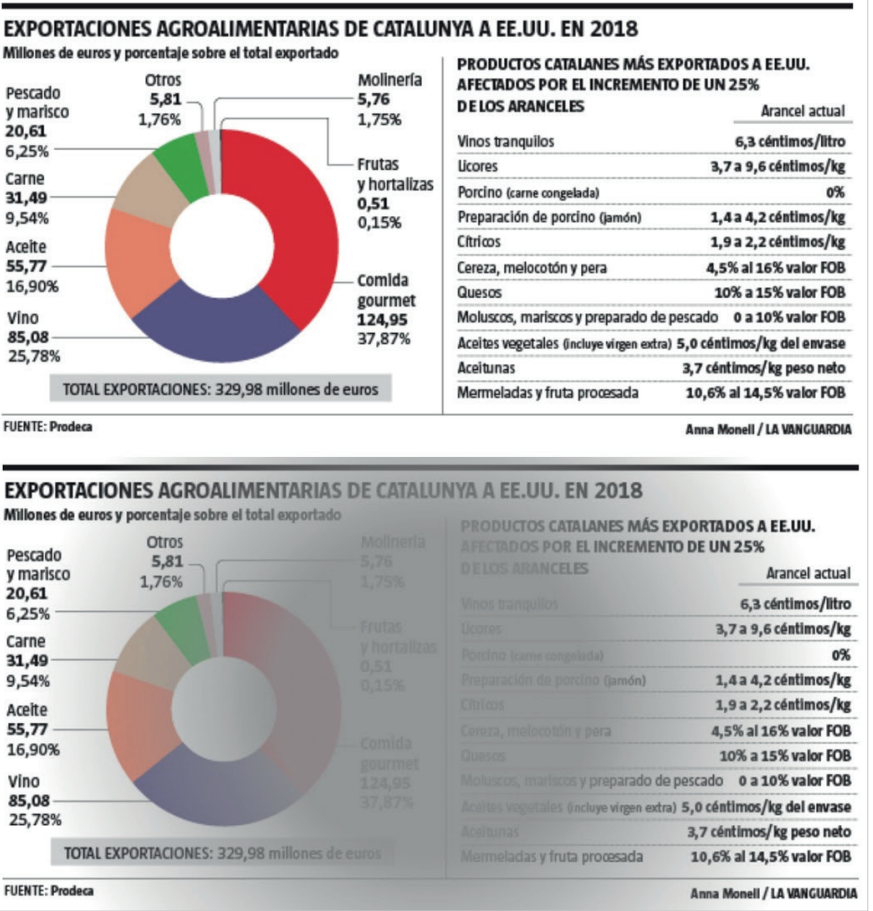

Figura 2. En la parte superior, gráfico visto por una persona sin discapacidad visual. En la parte inferior, simulación del resultado de ver el mismo gráfico por parte de una persona con la visión central reducida como consecuencia de una degeneración macular. Fuente del gráfico original: La vanguardia; de la simulación: Autores.

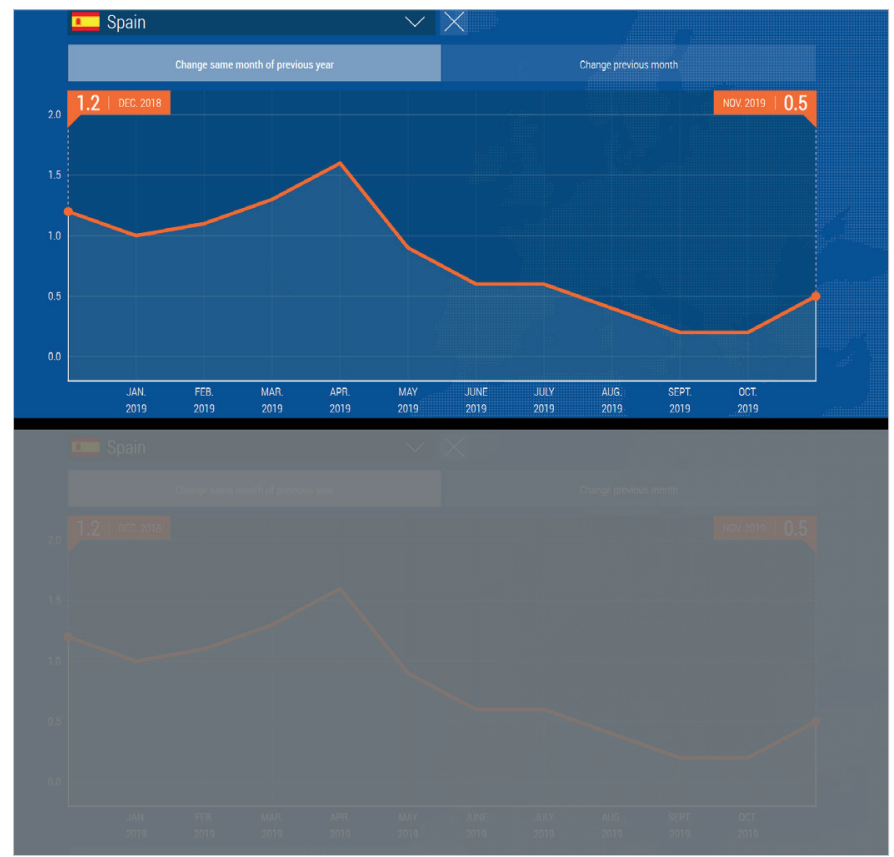

Figura 3. En la parte superior, gráfico sobre la evolución de la inflación en España disponible en el sitio web de Eurostat. En la parte inferior, simulación del resultado de ver el mismo gráfico por parte de una persona con alta sensibilidad al contraste. Fuente del gráfico original: Eurostat; de la simulación: Autores. 


\section{Método}

\subsection{Creación de la lista de indicadores}

Uno de los principales problemas en la construcción de heurísticas de dominio radica en la escasa información proporcionada por sus autores sobre el proceso de formulación, especificación, validación y refinamiento de los indicadores (Quiñones et al., 2018). En concreto, Hermawati y Lawson (2016), destacan como principal problema importantes deficiencias en el proceso de validación, así como la falta de rigurosidad, robustez y estandarización en el análisis de la eficacia de los indicadores heurísticos propuestos.

Para la selección, descripción, especificación y refinamiento del conjunto de heurísticos se ha seguido el método propuesto por Quiñones et al. (2018), el cual se ha complementado con las métricas propuestas por Jiménez et al. (2017) para la validación en comparación a otras listas de heurísticas existentes. El método consta de 8 fases, de las cuales las 6 primeras consisten en:

1) exploratoria, en la que se propone realizar una revisión de la bibliografía publicada con el objetivo de recopilar información relevante para la construcción de la lista de indicadores. Para ello se realizó una revisión de alcance de la bibliografía cuyos resultados se encuentran disponibles en Alcaraz-Martínez et al. (2020);

2) evaluaciones heurísticas con estos otros indicadores, una fase optativa que no se llevó a cabo dada la inexistencia de otros trabajos centrados en la evaluación de la accesibilidad de los gráficos estadísticos para personas con baja visión y VCD;

3) descriptiva, en la que se seleccionan y priorizan las cuestiones más importantes de la información recopilada en las fases anteriores;

4) correlacional, en la que se mapean los principios identificados con otras listas de indicadores heurísticos de interés. En nuestro caso con las WCAG 2.1 (2018a) y las propuestas de Koivunen y McCathieNevile (2001), Evergreen y Emery (2018) y Boudreau (2019);

5) selección, en la que se mantienen, adaptan o descartan los indicadores seleccionados en la fase 3 , con el objetivo de obtener una primera propuesta;

6) especificación, en la que se detalla formalmente el alcance de cada indicador (tabla 3);

7) validación de la lista de indicadores obtenidos a partir de diferentes métodos entre los cuales se encuentra la realización de evaluaciones heurísticas sobre un conjunto de sitios web representativos del dominio en cuestión. El trabajo que presentamos en este artículo es precisamente la primera evaluación conducida con el nuevo conjunto de indicadores heurísticos, la interpretación de sus resultados y la validación de los indicadores propuestos;

8) refinamiento, mejora del conjunto de indicadores en función de los resultados y comentarios obtenidos en la fase anterior.
Mujeres en altos cargos

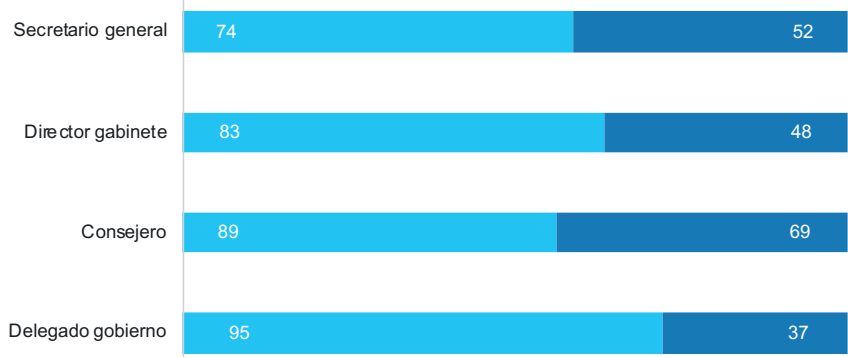

Mujeres en altos cargos

$\square \mathrm{H} \square \mathrm{M}$

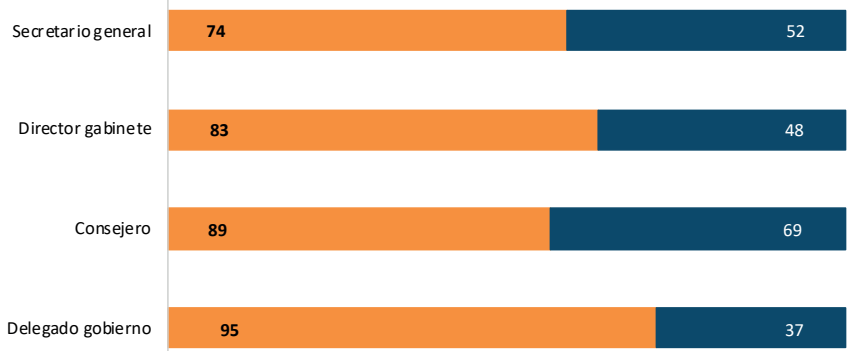

Figura 4. En la parte superior, los dos tonos de azul de las barras presentan un contraste insuficiente entre ellos (2,27:1 de 3:1). La etiqueta blanca con el valor numérico sobre el azul más claro, así como el texto del pie, también presentan un contraste insuficiente (2,11:1 y 3,79:1 de 4,5:1, respectivamente). En la parte inferior, el contraste entre barras es de 4,52:1 y los contrastes entre etiquetas negra/naranja y blanca/azul de $9,4: 1$ y 10,1:1, respectivamente. Para el pie se utiliza un negro $100 \%$ obteniendo el máximo contraste posible (21:1). Finalmente, se ha cambiado la fuente Arial, por la Tiresias, una fuente creada específicamente para mejorar la legibilidad de los textos para personas con baja visión. Fuente del gráfico superior: Adaptación de un gráfico publicado en El mundo. Fuente del gráfico inferior: adaptación de los autores.
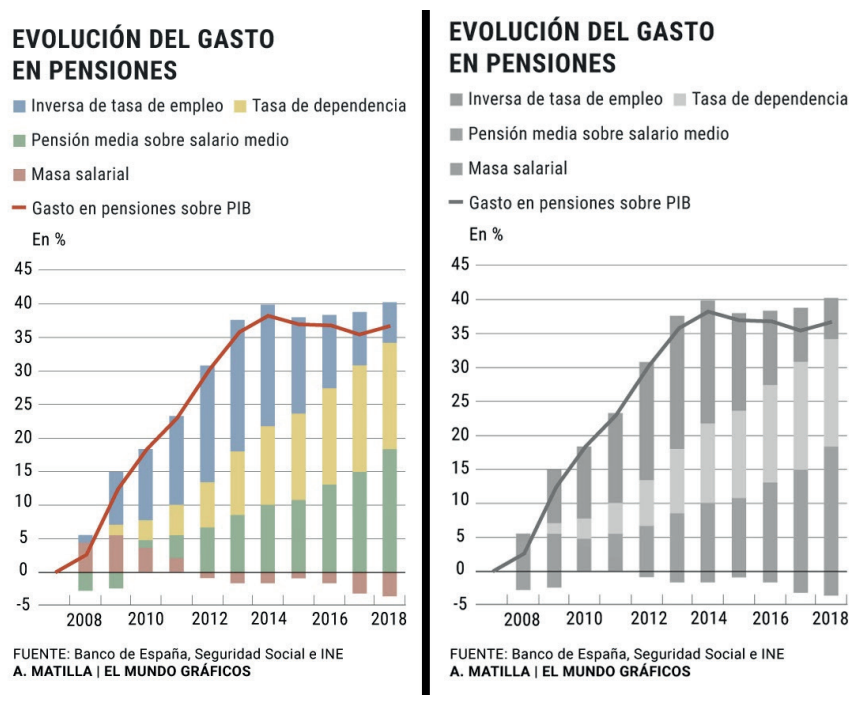

Figura 5. A la izquierda, gráfico visto por una persona con una completa percepción del color. A la derecha, simulación del resultado de ver el mismo gráfico por parte de una persona con acromatopsia (también llamada monocromatismo). Fuente del gráfico original: El mundo, de la simulación: Autores. 


\subsection{Planteamiento y ejecución de la evaluación}

Los resultados del trabajo de Nielsen (1992) muestran la necesidad de involucrar a varios evaluadores para poder encontrar todos los problemas presentes en la interfaz. Su recomendación es que participen entre 3 y 5 evaluadores, ya que añadir personas adicionales al proceso implica una relación entre beneficios y coste difícilmente justificable por el pobre incremento en la cantidad de errores descubiertos (Nielsen; Landauer, 1993). En este caso se ha contado con 4 evaluadores, todos ellos con experiencia previa en evaluaciones heurísticas, auditorías de accesibilidad y en el trabajo con usuarios con baja visión.

El proceso de evaluación tuvo lugar entre los días 5 y 13 de octubre de 2019. Cada evaluador trabajó de manera individual con el objetivo de garantizar evaluaciones independientes e imparciales. Una vez finalizado el proceso y, siguiendo las recomendaciones de Nielsen (1994), se llevó a cabo una reunión en la que los evaluadores pudieron comunicarse y agregar sus hallazgos con el objetivo de poner en común aspectos relacionados tanto con los problemas encontramos en la interfaz, como con los mismos indicadores heurísticos.

La lista de indicadores heurísticos propuesta está formada por 18 indicadores que cubren aspectos de la información que transmite el gráfico (título, ejes, alternativas de texto...), su presentación visual (fuente tipográfica, colores...) y el comportamiento y funciones presentes (personalización, compatibilidad con los lectores de pantalla...).

En relación con el perfil de baja visión al que benefician, la distribución de los indicadores es la siguiente:

- 3 indicadores pensados para usuarios que presentan un resto visual muy bajo y que emplean un lector de pantalla como ayuda técnica principal o como complemento al magnificador de pantalla;

- 5 indicadores que contemplan aspectos que pueden beneficiar a usuarios con un resto visual no tan bajo como el anterior, pero que aun así precisan del uso de ayudas como magnificadores de pantalla;

- 1 indicador pensado para satisfacer las necesidades de los usuarios con VCD;

- 1 indicador que cubre la sensibilidad al contraste; y

- 8 indicadores de carácter más general que constituyen buenas prácticas que benefician a cualquier tipo de lector.

Al tratarse de indicadores que dependen de la opinión de expertos y, con el objetivo de conseguir unos resultados cuantitativos que posteriormente posibilitaran la comparación entre medios o el nivel de accesibilidad respecto a una puntuación máxima, se utilizó una escala de Likert de 7 puntos para el cálculo del grado de cumplimiento de cada ítem, cuyo rango va de 0 (peor puntuación posible) a 6 (mejor puntuación posible). Adicionalmente, se han añadido las opciones "No aplica" y "No es problema", para aquellos casos en los cuales no sea pertinente la pregunta, o en los que el hecho de no cumplir con el indicador no deriva en un problema de accesibilidad, respectivamente. Un ejemplo de caso en el que un indicador no aplica, lo podemos encontrar en la no necesidad de disponer de una leyenda en el caso de gráficos estadísticos con una única serie de datos, o en la no necesidad de utilizar colores seguros o patrones cuando el gráfico sólo muestra una marca. Por lo que respecta al valor "No es problema", aplica en casos como, por ejemplo, cuando se incluyen abreviaturas que no se desarrollan pero que son de uso común y muy conocidas por la audiencia.

El uso de las escalas de Likert permite al evaluador graduar su respuesta ante afirmaciones complejas en las cuales una respuesta afirmativa o negativa no son suficientes para valorar el cumplimiento del indicador. Es decir, convierte un indicador cualitativo en un valor cuantitativo. En la bibliografía científica encontramos numerosos ejemplos de experimentos que las han empleado para la puntuación de las heurísticas en procesos de evaluación de otros dominios específicos. Sin ánimo de ser exhaustivos, algunos trabajos de referencia son los de Mankoff et al. (2003), Inostroza et al. (2013), Wetzlinger, Auinger y Dörflinger (2014), Joyce y Lilley (2014), Mi et al. (2014) o Bonastre y Granollers (2014).

Dado que uno de los objetivos de este trabajo era validar la lista de indicadores heurísticos y, al ser la primera vez que se aplicaba en una evaluación, el sistema de puntuación anteriormente descrito se complementó con un campo de respuesta abierta para cada indicador en el que los evaluadores pudieron especificar las razones de la puntuación, así como anotar problemas de accesibilidad concretos y ciertos datos que les fueron solicitados para facilitar una posterior lectura enriquecida de los resultados. Esto ha complementado la evaluación puramente heurística con datos adicionales y homogéneos que hacen posible ver con mayor exactitud la frecuencia con la que se dan diversos problemas clave. Entre los datos solicitados, se recogieron características técnicas (formato, resolución, profundidad de bits...), ratios de contraste, textos alternativos, problemas asociados al título, abreviaturas, o la fuente de los datos, entre otros (tablas 8,9 y 10).
Tabla 1. Respuestas posibles según el grado de cumplimiento de cada indicador

\begin{tabular}{|c|l|}
\hline Evaluación & \multicolumn{1}{|c|}{ Nivel de cumplimiento } \\
\hline- & No aplica \\
\hline- & No es problema \\
\hline 0 & No cumplimiento \\
\hline 1 & Cumplimiento muy bajo \\
\hline 2 & Cumplimiento bajo \\
\hline 3 & Cumplimiento aceptable \\
\hline 4 & Cumplimiento alto \\
\hline 5 & Cumplimiento muy alto \\
\hline 6 & Cumplimiento excelente \\
\hline
\end{tabular}

Tras la aplicación de la escala, se utiliza un sistema de ponderación que posibilita asignar pesos distintos según la importancia de cada indicador. Su importancia viene determinada por los criterios especificados en la tabla 2. 
Tabla 2. Criterios de aplicación para el sistema de ponderación

\begin{tabular}{|l|l|}
\hline Criterio & Ponderación \\
\hline $\begin{array}{l}\text { En caso de no cumplirse, uno o más perfiles de usuario no tendrá una experiencia de usuario satisfactoria al consultar el } \\
\text { gráfico, comprometiéndose levemente su accesibilidad para uno o más perfiles de usuario con baja visión. }\end{array}$ & xn caso de estar presente la accesibilidad del gráfico mejora levemente. \\
\hline $\begin{array}{l}\text { En caso de no cumplirse, uno o más perfiles de usuarios tendrá serias dificultades para percibir la información del gráfico, } \\
\text { comprometiéndose gravemente su accesibilidad para uno o más perfiles de usuario con baja visión. } \\
\text { Funcionalidad que de estar presente mejora mucho la accesibilidad del gráfico. }\end{array}$ & x2 \\
\hline $\begin{array}{l}\text { En caso de no cumplirse, uno o más perfiles de usuarios será incapaz de percibir la información del gráfico, comprometién- } \\
\text { Funcionalidad que de estar presente mejora enormemente la accesibilidad del gráfico. }\end{array}$ & x3 \\
\hline
\end{tabular}

Para obtener un valor final ponderado sobre 10, se emplea la siguiente fórmula:

\section{$\underline{\left(\sum_{i=1}^{n} \text { puntuación asignada } x \text { ponderación }\right) * 10}$ $\sum_{i=1}^{n}$ máxima puntuación $x$ ponderación}

Donde $n$ es el número de indicadores heurísticos.

La lista de indicadores heurísticos utilizada, junto con su definición, el perfil de usuario beneficiado de su cumplimiento y su ponderación se puede consultar en la tabla 3.

Tabla 3. Lista de indicadores heurísticos

\begin{tabular}{|c|c|c|c|c|c|}
\hline ID & Nombre & Definición & Lista de verificación & $\begin{array}{c}\text { Perfil de } \\
\text { usuario } \\
\text { beneficiado }\end{array}$ & Ponderación \\
\hline $\mathrm{H} 1$ & Título & $\begin{array}{l}\text { El gráfico debe contar con un título } \\
\text { breve y descriptivo que ayude al lector } \\
\text { a identificarlo y diferenciarlo del resto } \\
\text { que aparecen en la misma página, per- } \\
\text { mitiéndoles navegar así entre ellos. }\end{array}$ & $\begin{array}{l}\text { El gráfico tiene un título. } \\
\text { El título es breve y descriptivo. } \\
\text { El título ofrece una primera aproximación al } \\
\text { contenido del gráfico y ayuda a diferenciarlo del } \\
\text { resto de gráficos del documento. } \\
\text { El título es texto real y no una imagen de texto. }\end{array}$ & $\begin{array}{l}\text { Cualquier } \\
\text { usuario. }\end{array}$ & $\mathrm{x} 1$ \\
\hline $\mathrm{H} 2$ & Leyenda & $\begin{array}{l}\text { El gráfico debe ofrecer leyendas que } \\
\text { asocian unívocamente esquemas de } \\
\text { color, patrones o formas utilizados en } \\
\text { el gráfico con sus respectivas variables, } \\
\text { siempre que sea necesario. }\end{array}$ & $\begin{array}{l}\text { El gráfico cuenta con una leyenda. } \\
\text { La leyenda explica la codificación empleada en } \\
\text { el gráfico. } \\
\text { La leyenda es texto real y no una imagen de } \\
\text { texto. }\end{array}$ & $\begin{array}{l}\text { Cualquier } \\
\text { usuario. }\end{array}$ & $x 1$ \\
\hline $\mathrm{H} 3$ & Ejes & $\begin{array}{l}\text { Los ejes del gráfico deben ser visibles } \\
\text { y sus etiquetas adecuadas concisas y } \\
\text { claras. }\end{array}$ & $\begin{array}{l}\text { El gráfico cuenta con los ejes necesarios. } \\
\text { Los ejes están etiquetados. } \\
\text { Las etiquetas son horizontales. } \\
\text { Si es pertinente, la escala y la unidad de medida } \\
\text { se incluyen en el eje. } \\
\text { Se incluye una cuadrícula sólo si es necesario. }\end{array}$ & $\begin{array}{l}\text { Cualquier } \\
\text { usuario. }\end{array}$ & $x 1$ \\
\hline $\mathrm{H} 4$ & Pie & $\begin{array}{l}\text { El gráfico debe contar con un pie que } \\
\text { contribuya a facilitar la compresión } \\
\text { de la información que se comunica, a } \\
\text { excepción de que se trate de un gráfico } \\
\text { muy simple que no lo precise. }\end{array}$ & $\begin{array}{l}\text { El gráfico cuenta con un pie. } \\
\text { El pie no se limita a repetir el título. } \\
\text { El pie proporciona información adicional. } \\
\text { Si corresponde, el pie ofrece información sobre } \\
\text { los detalles del análisis estadístico (desviación } \\
\text { estándar, valor p...) } \\
\text { El pie se ofrece como texto y no como una } \\
\text { imagen de texto. }\end{array}$ & $\begin{array}{l}\text { Cualquier } \\
\text { usuario. }\end{array}$ & $\mathrm{x} 1$ \\
\hline H5 & $\begin{array}{l}\text { Abrevia- } \\
\text { turas }\end{array}$ & $\begin{array}{l}\text { Las abreviaturas utilizadas se desarro- } \\
\text { llan para facilitar su compresión. }\end{array}$ & $\begin{array}{l}\text { Las abreviaturas se desarrollan siguiendo un } \\
\text { método estándar respaldado por las ayudas } \\
\text { técnicas (elemento <abbr>, enlace a la forma } \\
\text { desarrollada, etc.) } \\
\text { Las formas desarrolladas se muestran como } \\
\text { texto real y no como una imagen de texto. }\end{array}$ & $\begin{array}{l}\text { Cualquier } \\
\text { usuario. }\end{array}$ & $x 1$ \\
\hline H6 & $\begin{array}{l}\text { Fuente de } \\
\text { datos }\end{array}$ & $\begin{array}{l}\text { Junto al gráfico, preferiblemente cerca } \\
\text { del pie, se ofrece información acerca } \\
\text { de la fuente de los datos (institución, } \\
\text { conjunto de datos, fecha y enlace) }\end{array}$ & $\begin{array}{l}\text { En algún lugar del gráfico, preferiblemente en el } \\
\text { pie o cerca de él, se ofrece información sobre la } \\
\text { fuente de los datos. } \\
\text { En la fuente de datos se identifica la institución } \\
\text { o empresa y se enlaza al conjunto de datos del } \\
\text { que proceden los datos. } \\
\text { La fuente de datos se muestra como texto y no } \\
\text { como una imagen de texto. }\end{array}$ & $\begin{array}{l}\text { Cualquier } \\
\text { usuario. }\end{array}$ & $x 1$ \\
\hline
\end{tabular}




\begin{tabular}{|c|c|c|c|c|c|}
\hline ID & Nombre & Definición & Lista de verificación & $\begin{array}{c}\text { Perfil de } \\
\text { usuario } \\
\text { beneficiado }\end{array}$ & Ponderación \\
\hline H7 & $\begin{array}{l}\text { Versión } \\
\text { impresa }\end{array}$ & $\begin{array}{l}\text { Se ofrece una versión del gráfico opti- } \\
\text { mizada para impresión para aquellos } \\
\text { usuarios que prefieran la consulta en } \\
\text { este otro medio. }\end{array}$ & $\begin{array}{l}\text { Es posible imprimir una versión del gráfico } \\
\text { optimizada para el medio impreso. } \\
\text { La versión impresa presenta una buena legibi- } \\
\text { lidad. } \\
\text { La versión impresa mantiene una buena legi- } \\
\text { bilidad, incluso cuando se imprime en blanco } \\
\text { y negro. }\end{array}$ & $\begin{array}{c}\text { Cualquier } \\
\text { usuario. }\end{array}$ & $\mathrm{x} 1$ \\
\hline H8 & $\begin{array}{c}\text { Alternativa } \\
\text { textual }\end{array}$ & $\begin{array}{l}\text { El gráfico cuenta con un texto alter- } \\
\text { nativo que informa brevemente sobre } \\
\text { el contenido del gráfico y ayuda a } \\
\text { los usuarios a determinar si desean } \\
\text { obtener más información al respecto. Si } \\
\text { existe una descripción larga asociada al } \\
\text { gráfico, se informa sobre ella. }\end{array}$ & $\begin{array}{l}\text { El gráfico cuenta con una alternativa textual. } \\
\text { La alternativa textual es breve y descriptiva. } \\
\text { La alternativa textual no es redundante con el } \\
\text { título. }\end{array}$ & $\begin{array}{l}\text { Baja visión } \\
\text { grave, espe- } \\
\text { cialmente } \\
\text { usuarios de } \\
\text { lector de } \\
\text { pantalla. }\end{array}$ & $\mathrm{x} 1$ \\
\hline H9 & $\begin{array}{l}\text { Descrip- } \\
\text { ción larga }\end{array}$ & $\begin{array}{l}\text { Todo gráfico complejo cuenta con una } \\
\text { descripción larga que ofrece informa- } \\
\text { ción equivalente. }\end{array}$ & $\begin{array}{l}\text { La descripción larga proporciona información } \\
\text { detallada sobre lo que se presenta visualmente, } \\
\text { incluidas escalas, valores, relaciones y tendencias. } \\
\text { Los valores de los datos se proporcionan a } \\
\text { través de una tabla de datos. } \\
\text { Los gráficos están estructuralmente asociados } \\
\text { con la descripción larga. }\end{array}$ & $\begin{array}{l}\text { Baja visión } \\
\text { grave, espe- } \\
\text { cialmente } \\
\text { usuarios de } \\
\text { lector de } \\
\text { pantalla. }\end{array}$ & $x 3$ \\
\hline $\mathrm{H} 10$ & $\begin{array}{l}\text { Colores } \\
\text { seguros }\end{array}$ & $\begin{array}{l}\text { Los colores empleados en el gráfico } \\
\text { para transmitir información pueden } \\
\text { ser distinguidos por las personas con } \\
\text { diferentes perfiles de VCD. }\end{array}$ & $\begin{array}{l}\text { Se emplea un máximo de } 5 \text { colores seguros } \\
\text { para diferenciar variables cualitativas, ordinales } \\
\text { o cuantitativas. } \\
\text { Alternativamente, los valores se diferencian } \\
\text { mediante patrones o texturas. }\end{array}$ & VCD. & $x 3$ \\
\hline $\mathrm{H} 11$ & Contraste & $\begin{array}{l}\text { Entre el texto y el fondo existe un contras- } \\
\text { te mínimo de 4,5:1. Entre los elementos } \\
\text { no textuales (líneas, barras, etc.) adya- } \\
\text { centes del gráfico, existe un contraste } \\
\text { mínimo de 3:1. }\end{array}$ & $\begin{array}{l}\text { Los colores empleados en el gráfico para } \\
\text { transmitir información son distinguibles para } \\
\text { los diferentes perfiles de VCD (protanopia, deu- } \\
\text { teranopia, tritanopia, acromatopsia...). }\end{array}$ & $\begin{array}{l}\text { Sensibilidad } \\
\text { al contraste. }\end{array}$ & $x 3$ \\
\hline $\mathrm{H} 12$ & Legibilidad & $\begin{array}{l}\text { El diseño del gráfico se basa en criterios } \\
\text { de composición de textos que aseguran } \\
\text { una correcta legibilidad (fuente tipográ- } \\
\text { fica, interlineado, espacio entre letras y } \\
\text { palabras, uso comedido de mayúsculas } \\
\text { y versalitas, etc.) }\end{array}$ & $\begin{array}{l}\text { Se usa una fuente tipográfica adecuada para } \\
\text { baja visión (sans serif) como, por ejemplo: Arial, } \\
\text { Helvetica, Courier o Verdana, o fuentes diseñadas } \\
\text { para baja visión como Tiresias, APHont o Eido. } \\
\text { Se valora el uso de un tamaño de texto razona- } \\
\text { ble, ampliable si el usuario lo precisa. } \\
\text { El espacio entre letras y el espacio entre pala- } \\
\text { bras deberían ser suficientes, el espacio entre } \\
\text { líneas debería ser } 1,5 \\
\text { El texto debe dejarse alineado a la izquierda. } \\
\text { Se evita la silabificación. } \\
\text { Se evita un uso excesivo de mayúsculas, versali- } \\
\text { tas y cursivas. }\end{array}$ & $\begin{array}{l}\text { Baja visión } \\
\text { moderada y } \\
\text { grave. }\end{array}$ & $x 2$ \\
\hline $\mathrm{H} 13$ & $\begin{array}{l}\text { Calidad de } \\
\text { la imagen }\end{array}$ & $\begin{array}{l}\text { Todos los gráficos, en particular los } \\
\text { gráficos en formato de mapa de bits } \\
\text { cuentan con una calidad suficiente para } \\
\text { su correcta visualización y admiten un } \\
\text { zoom mínimo de } 200 \% \text { sin desenfocar- } \\
\text { se, ni pixelarse. }\end{array}$ & $\begin{array}{l}\text { El tamaño de imagen (en píxeles) debería ser } \\
\text { suficiente para llegar al } 200 \% \text { de zoom sin que } \\
\text { se desenfoque o se pixele. } \\
\text { Los formatos de archivo más adecuados son } \\
\text { PNG preferiblemente, o JPG con un nivel de } \\
\text { compresión adecuado. } \\
\text { La resolución es de, al menos, } 150 \text { ppp. } \\
\text { La profundidad de bits es de } 8 \text { a } 32 \text { bits. }\end{array}$ & $\begin{array}{c}\text { Baja visión } \\
\text { moderada y } \\
\text { grave. }\end{array}$ & $x 3$ \\
\hline $\mathrm{H} 14$ & $\begin{array}{l}\text { Redimen- } \\
\text { sionado }\end{array}$ & $\begin{array}{l}\text { El gráfico se puede ampliar hasta un } \\
200 \% \text { sin la necesidad de contar con } \\
\text { ninguna ayuda técnica diferente al } \\
\text { navegador. Una vez ampliado, ningún } \\
\text { elemento se superpone al gráfico y } \\
\text { todas sus funcionalidades originales } \\
\text { continúan estando disponibles. }\end{array}$ & $\begin{array}{l}\text { Cuando se aplica un zoom de hasta un } 200 \% \\
\text { sobre el gráfico, no se superpone ningún otro } \\
\text { elemento presente en la página. El gráfico } \\
\text { debe poder leerse sin tener que hacer scroll } \\
\text { horizontal. }\end{array}$ & $\begin{array}{l}\text { Baja visión } \\
\text { moderada y } \\
\text { grave. }\end{array}$ & $x 2$ \\
\hline $\mathrm{H} 15$ & $\begin{array}{l}\text { Sin obstá- } \\
\text { culos en la } \\
\text { visualiza- } \\
\text { ción }\end{array}$ & $\begin{array}{l}\text { En ocasiones, los editores de contenido } \\
\text { utilizan elementos como marcas de } \\
\text { agua o de autoría que superponen a } \\
\text { las imágenes de texto, SVG o Canvas, } \\
\text { dificultando su lectura. El objetivo de } \\
\text { este indicador es asegurar que ningún } \\
\text { elemento externo al gráfico dificulta o } \\
\text { impide parcial o totalmente su lectura }\end{array}$ & $\begin{array}{l}\text { No se superpone ningún elemento sobre el } \\
\text { gráfico que pudiera comprometer su lectura } \\
\text { (marcas de agua, publicidad...) }\end{array}$ & $\begin{array}{c}\text { Cualquier } \\
\text { usuario. }\end{array}$ & $x 3$ \\
\hline
\end{tabular}




\begin{tabular}{|c|c|c|c|c|c|}
\hline ID & Nombre & Definición & Lista de verificación & $\begin{array}{l}\text { Perfil de } \\
\text { usuario } \\
\text { beneficiado }\end{array}$ & Ponderación \\
\hline $\mathrm{H} 16$ & $\begin{array}{l}\text { Foco } \\
\text { visible }\end{array}$ & $\begin{array}{l}\text { Se muestra un indicador visible para } \\
\text { todos aquellos elementos del gráfico } \\
\text { que puedan recibir el foco del ratón, } \\
\text { teclado o táctil. Este criterio no aplica a } \\
\text { los gráficos en formato de mapa de bits, } \\
\text { sino sólo a los gráficos en formato SVG } \\
\text { o implementados con bibliotecas de } \\
\text { JavaScript. }\end{array}$ & $\begin{array}{l}\text { Cuando un elemento seleccionable de un } \\
\text { gráfico recibe el foco del ratón o el teclado, se } \\
\text { muestra algún tipo de indicador que lo destaca. }\end{array}$ & $\begin{array}{l}\text { Baja visión } \\
\text { moderada y } \\
\text { grave. }\end{array}$ & $\mathrm{x} 1$ \\
\hline $\mathrm{H} 17$ & $\begin{array}{l}\text { Nave- } \\
\text { gación } \\
\text { indepen- } \\
\text { diente del } \\
\text { dispositivo }\end{array}$ & $\begin{array}{l}\text { Tanto en dispositivos de sobremesa, } \\
\text { como en dispositivos móviles es posible } \\
\text { navegar mediante distintas interfaces } \\
\text { (ratón, teclado o gestos táctiles). Para } \\
\text { cumplir este indicador, los tipos de } \\
\text { eventos o interacciones disponibles de- } \\
\text { ben ser identificables y poder operarse } \\
\text { mediante los diferentes tipos de inter- } \\
\text { faces disponibles. Este criterio no aplica } \\
\text { a los gráficos en formato de mapa de } \\
\text { bits, sino sólo a los gráficos en formato } \\
\text { SVG o implementados con bibliotecas } \\
\text { de JavaScript. }\end{array}$ & $\begin{array}{l}\text { Es posible navegar a través de los elementos del } \\
\text { gráfico mediante el teclado. } \\
\text { Es posible navegar a través de los elementos del } \\
\text { gráfico mediante el ratón. } \\
\text { Es posible navegar a través de los elementos del } \\
\text { gráfico mediante gestos táctiles. }\end{array}$ & $\begin{array}{l}\text { Baja visión } \\
\text { grave, espe- } \\
\text { cialmente } \\
\text { usuarios de } \\
\text { lector de } \\
\text { pantalla. } \\
\text { También } \\
\text { usuarios con } \\
\text { discapacidad } \\
\text { motriz. }\end{array}$ & x3 \\
\hline $\mathrm{H} 18$ & $\begin{array}{l}\text { Personali- } \\
\text { zación }\end{array}$ & $\begin{array}{l}\text { Se permite a los usuarios personalizar } \\
\text { las características de los gráficos (paleta } \\
\text { de colores, contraste, familia tipográfi- } \\
\text { ca, tamaño del texto, interlineado, etc.). } \\
\text { Cumplir con este indicador implica el } \\
\text { uso de tecnologías compatibles con } \\
\text { las ayudas técnicas pensadas para para } \\
\text { este cometido. Alternativamente, es } \\
\text { posible alcanzar el indicador, ofre- } \\
\text { ciendo un sistema propio que permita } \\
\text { personalizar la apariencia del gráfico. }\end{array}$ & $\begin{array}{l}\text { El gráfico ofrece opciones de personalización } \\
\text { específica. } \\
\text { El gráfico es compatible con su personalización } \\
\text { mediante terceras aplicaciones (ayudas técni- } \\
\text { cas, extensiones de navegador. }\end{array}$ & $\begin{array}{l}\text { Baja visión } \\
\text { moderada y } \\
\text { grave y VCD }\end{array}$ & $x 2$ \\
\hline
\end{tabular}

Finalmente, con el objetivo de validar la eficacia del nuevo conjunto de indicadores (d) se calculan las siguientes métricas propuestas por Jiménez et al. (2017) considerando tanto los resultados obtenidos con las heurísticas propuestas, como con un conjunto de heurísticas de control (c) (anexo 1) formado por 14 criterios de conformidad extraídos de las WCAG 2.1. Para la selección de este subconjunto de criterios de conformidad se han tenido en cuenta sólo aquellos aplicables al perfil de usuario objeto de estudio de esta investigación. Esto incluye criterios referidos a la inclusión de alternativas textuales para el contenido gráfico, el uso del color, contraste, aspectos relacionados con la legibilidad como el espaciado del texto o el redimensionado de imágenes, o la compatibilidad en el acceso al contenido con interfaces como el teclado. En este último caso, conviene destacar que un importante porcentaje de personas con baja visión -el 39\% de acuerdo con una encuesta conducida por WebAIM (2013)-, especialmente aquellas con una baja visión severa, acceden al contenido a través de lectores de pantalla en combinación con el teclado y otras ayudas técnicas como los magnificadores de pantalla, en detrimento del uso del ratón. Según la encuesta de WebAIM, el teclado es utilizado siempre o habitualmente por el $47,5 \%$ de las personas encuestadas como periférico para navegar por páginas web.

Tasa de problemas únicos: ayuda a descubrir cuál de los dos grupos de heurísticas encuentra más problemas únicos ( $p$ )

$$
\Phi p=\frac{P d}{P c}
$$

Tasa de dispersión de problemas: mide la distribución de los problemas ( $\delta$ ) en cada grupo de heurísticas a través de la desviación estándar de dicha distribución.

$$
\delta p=\frac{\delta c}{\delta d}
$$

Tasa de severidad: la relación entre la severidad promedio $(\lambda)$ de los problemas detectados con uno y otro grupo. Para el cálculo de la severidad se tuvieron en cuenta los tres niveles de ponderación propuestos para el conjunto de heurísticas presentado y los tres niveles de conformidad propios de las WCAG (A, AA y AAA).

$$
\lambda p=\frac{\lambda d}{\lambda c}
$$


Tasa de especificidad: relaciona los promedios de especificidad $(\varepsilon)$ de ambos grupos. Para calcularlo se tuvieron en cuenta dos niveles de especificidad: uno para los indicadores aplicables a cualquier tipo de sitio web o aplicación, y otro para los indicadores sólo aplicables a gráficos estadísticos.

$$
\varepsilon p=\frac{\varepsilon d}{\varepsilon c}
$$

En todas las métricas anteriores, si el resultado es superior a 1, el conjunto de heurísticas propuesto presenta un mejor rendimiento.

\subsection{Selección de la muestra}

Una vez establecido el método, a partir de los principales medios generalistas nacionales y de dos diarios internacionalmente reconocidos por su buena labor en el ámbito de la visualización de datos, se propuso una lista de gráficos estadísticos que posibilitaran comparar el estado de la accesibilidad de medios representativos españoles con dos referentes internacionales. Para la confección de la lista de medios nacionales se tuvieron en cuenta los datos del Estudio general de medios (EGM) (Asociación para la Investigación de Medios de Comunicación, 2019), uno de los principales sistemas de medición de audiencias en España. Los diarios con mayor audiencia de acuerdo con la segunda ola de 2019 son los siguientes:

- El país.

https://elpais.com

- El mundo.

https://www.elmundo.es

- La vanguardia.

https://www.lavanguardia.com

- $A B C$.

https://www.abc.es

- El periódico.

https://www.elperiodico.com

Por lo que respecta a los dos diarios internacionales seleccionados, más allá de ser referentes internacionales en la elaboración de gráficos e infografías, también son, según Alexa ${ }^{1}$, los dos diarios digitales que mayor tráfico reciben a nivel mundial, situados en las posiciones 3 y 6 de la categoría de sitios de Internet de noticias, respectivamente:

- The New York times.

https://www.nytimes.com

- The guardian.

https://www.theguardian.com

El procedimiento de selección de los gráficos a analizar ha consistido en el vaciado sistemático de los sitios webs de los diarios durante el mes de octubre de 2019, seleccionándose un total de 5 gráficos de cada uno de los medios analizados, lo que supone una muestra total de 35 gráficos. La lista completa de gráficos se puede consultar en el anexo 2. Durante el proceso de selección se incluyeron mayoritariamente gráficos de barras y líneas, los más comunes en la prensa, alguno circular pues, aunque su uso es controvertido, sigue Tabla 4. Distribución según tipo de gráfico

\begin{tabular}{|l|c|}
\hline \multicolumn{1}{|c|}{ Tipo de gráfico } & Número de gráficos analizados \\
\hline Barras & 14 \\
\hline Líneas & 13 \\
\hline Circular & 4 \\
\hline Barras apiladas & 2 \\
\hline Barras y líneas & 1 \\
\hline Diagrama de puntos & 1 \\
\hline
\end{tabular}

siendo un gráfico común, y unas pocas variaciones de los dos principales también de uso generalizado, cuya distribución exacta se puede consultar en la tabla 4. Se han descartado otros tipos de visualizaciones complejas diferentes a gráficos estadísticos como infografías o gráficos con un componente geográfico.

\subsection{Tecnologías de apoyo}

Para la evaluación de los indicadores se utilizaron herramientas de soporte como:

- NoCoffee Vision Simulator ${ }^{2}$. Una extensión de navegador que simula los diferentes tipos de VCD y sensibilidad al contraste.

- Contrast Checker ${ }^{3}$. Una aplicación web que determina si la ratio de contraste entre dos colores alcanza los niveles de conformidad mínimos de las WCAG tanto para texto como para elementos gráficos (novedad introducida en las WCAG 2.1).

- Medialnfo4. Un programa que provee información de carácter técnico y metadatos de un fichero.

- NVDA 2019.2.15. Software lector de pantalla. 


\section{Resultados}

Los resultados de rendimiento (tabla 5) muestran que los indicadores propuestos son capaces de detectar una mayor cantidad de problemas únicos, presentan una mejor distribución de los problemas entre heurísticos y ayudan a detectar problemas más severos y específicos que las WCAG. Si bien estas directrices pueden presentar unos criterios de conformidad suficientes para evaluar la accesibilidad del contenido web, el hecho de tratarse de unas directrices pensadas para satisfacer las necesidades de un gran abanico de recursos digitales, hace que no aborden de manera específica todos los aspectos aplicables a los gráficos estadísticos.

La figura 6 muestra los resultados finales de la evaluación por gráfico. Por su parte, la figura 7 muestra las notas medias por diario y las medias nacional, internacional y global de las cuatro evaluaciones realizadas.

En relación con los heurísticos propuestos, algunos son aplicables a sólo un subgrupo de gráficos, como por ejemplo H5 aplicable solo a 19 gráficos, o H16 y H17 aplicables a 13 gráficos. Con mayor incidencia, pero no aplicable aún a todos los gráficos, $\mathrm{H} 2$ solo se ha podido medir en 28 de ellos.

H9 ha sido valorado en un $88,6 \%$ de las ocasiones con un 0 (no cumplimiento). Algunos heurísticos como $\mathrm{H} 2, \mathrm{H} 3, \mathrm{H} 5, \mathrm{H} 12, \mathrm{H} 13$ y $\mathrm{H} 14$, raramente bajan de una puntación de $1(5,4,7$, 5,1 y 8 veces, respectivamente). Otros nunca (H17) o raramente $(\mathrm{H} 5, \mathrm{H} 6, \mathrm{H} 9$ y $\mathrm{H} 16)$ obtienen la puntuación máxima. Heurísticos como H9 y H16 raramente obtienen una puntación igual o superior al 4 sobre 6 ( 3 y 5 veces respectivamente). $\mathrm{H} 17$ siempre se ha evaluado (en los casos que era aplicable) con un 0 . Este último valor fuerza a los autores a revisar este indicador en sucesivas versiones de la lista.

Por otro lado, 10 indicadores (H4, H5-H9, H11, $\mathrm{H} 16-\mathrm{H} 18)$ obtienen una valoración media por debajo de 3 sobre 6 (cumplimiento aceptable), de los cuales 4 ( $\mathrm{H} 5, \mathrm{H} 8-\mathrm{H} 9$ y $\mathrm{H} 17)$, por debajo de 1 sobre 6 y $3(\mathrm{H} 4, \mathrm{H} 16$ y H18) entre 1 y 2 . Es decir, en conjunto la realización de los gráficos en los aspectos reflejados por estos heurísticos está muy por debajo de lo deseable. Solo 3 indicadores tienen un cumplimiento entre 3 y 4 de media (aceptable) ( $\mathrm{H} 1, \mathrm{H} 10$ y H12) y solo 5 un cumplimiento entre 4 y 5 de media (cumplimiento alto) (H2-H3, H14-H15). Ninguno de ellos tiene un cumplimiento muy alto o excelente de media.
Tabla 5. Resultado de las métricas de rendimiento

\begin{tabular}{|l|l|}
\hline Tasa de problemas únicos & $340 / 134=2,54$ \\
\hline Tasa de dispersión de problemas & $0,68 / 0,45=1,52$ \\
\hline Tasa de severidad & $0,76 / 0,71=1,07$ \\
\hline Tasa de especificidad & $1,27 / 1=1,27$ \\
\hline
\end{tabular}

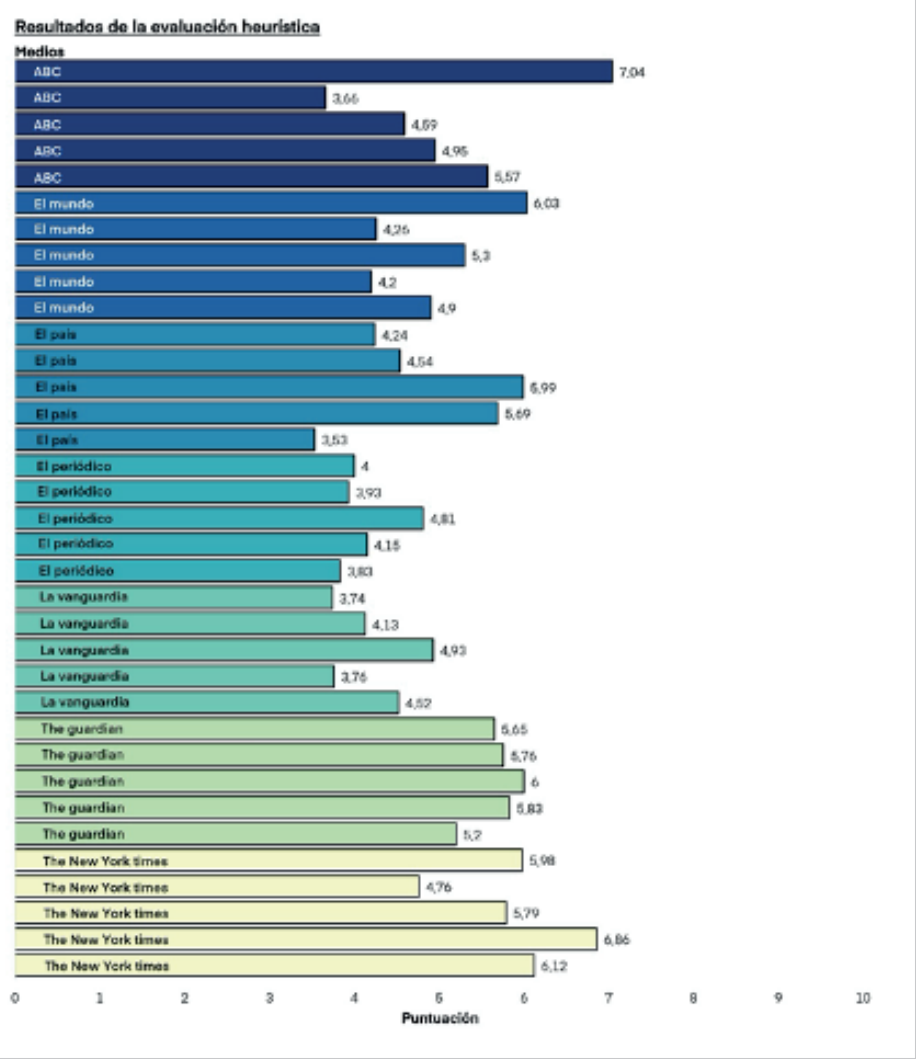

Figura 6. Resultados de la evaluación heurística

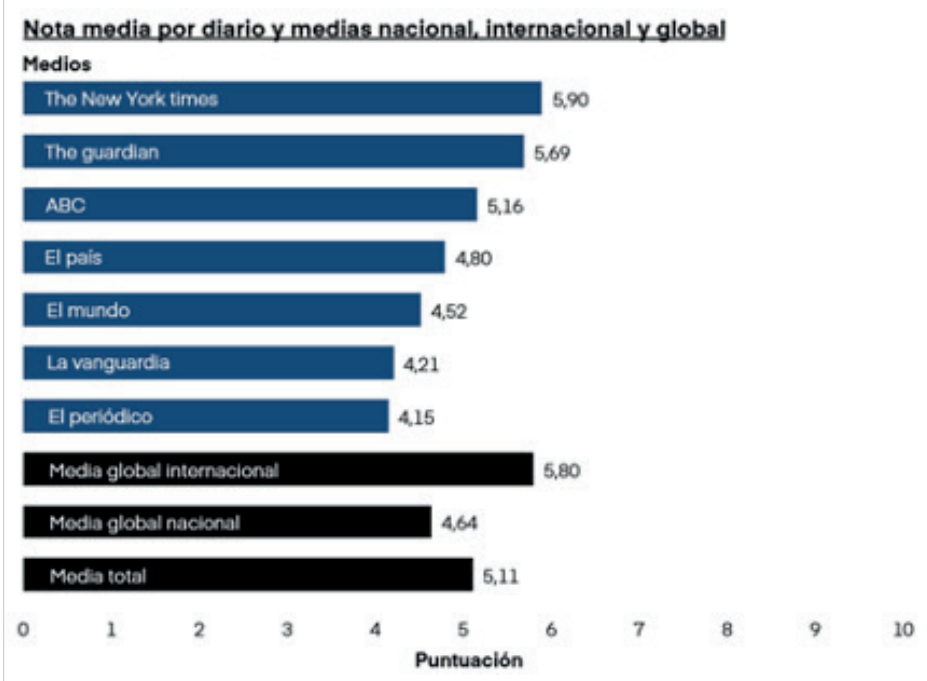

Figura 7. Nota media por diario y medias nacional, internacional y global de las cuatro evaluaciones realizadas

Si bien los resultados ponderados de la evaluación heurística se muestran sobre 10, esto no implica que alcanzar una nota de 5 signifique que el gráfico presenta una accesibilidad suficiente. Como se ha comentado anteriormente, la gran variabilidad presente en el perfil de usuarios con baja visión implica que no cumplir con indicadores como los relacionados con el contraste o el uso de colores seguros para las personas con VCD, resulte en gráficos que no serán accesibles para ellos. 
Desde un punto meramente cuantitativo, los gráficos presentes en los dos medios internacionales han obtenido mejores puntuaciones que los nacionales, en general por el mayor uso de gráficos vectoriales que facilitan la lectura y personalización del texto incluido en ellos, por mejores prácticas en la redacción de títulos y, en el caso de The guardian, por un mejor cumplimiento de los requisitos de contraste. Con ello podemos observar la importancia de un estilo editorial y del buen uso del software para la creación de gráficos empleado, caminos ambos que quiere potenciar la investigación llevada a cabo por los autores.

Las tablas 8, 9 y 10, muestran los datos adicionales de cada gráfico recogidos por los evaluadores.

Tabla 8. Características técnicas

\begin{tabular}{|c|c|c|c|c|c|}
\hline ID & Formato & Píxeles horizontales & Píxeles verticales & Profundidad de bits & Resolución en ppp \\
\hline 1 & JPG & 720 & 696 & 24 & 72 \\
\hline 2 & $J P G$ & 720 & 452 & 24 & 72 \\
\hline 3 & SVG & - & - & - & - \\
\hline 4 & JPG & 1.960 & 3.343 & 24 & 72 \\
\hline 5 & JPG & 1.960 & 1.164 & 24 & 72 \\
\hline 6 & JPG & 540 & 1.403 & 24 & 96 \\
\hline 7 & JPG & 600 & 400 & 24 & 96 \\
\hline 8 & JPG & 540 & 821 & 24 & 96 \\
\hline 9 & JPG & 542 & 921 & 24 & 72 \\
\hline 10 & SVG & - & - & - & - \\
\hline 11 & PNG & 185 & 303 & 32 & 300 \\
\hline 12 & PNG & 586 & 303 & 24 & 300 \\
\hline 13 & SVG & - & - & - & - \\
\hline 14 & PNG & 656 & 399 & 24 & 128 \\
\hline 15 & PNG & 656 & 970 & 24 & 72 \\
\hline 16 & JPG & 1.240 & 698 & 24 & 300 \\
\hline 17 & JPG & 2.125 & 1.456 & 24 & 300 \\
\hline 18 & $J P G$ & 510 & 345 & 24 & 96 \\
\hline 19 & JPG & 508 & 286 & 24 & 59 \\
\hline 20 & JPG & 1.593 & 1.718 & 24 & 72 \\
\hline 21 & JPG & 1.200 & 764 & 24 & 72 \\
\hline 22 & JPG & 1.200 & 674 & 24 & 72 \\
\hline 23 & SVG & - & - & - & - \\
\hline 24 & JPG & 1.200 & 674 & 24 & 72 \\
\hline 25 & JPG & 1.200 & 674 & 24 & 72 \\
\hline 26 & PNG & 1.140 & 308 & 32 & 96 \\
\hline 27 & SVG & - & - & - & - \\
\hline 28 & SVG & - & - & - & - \\
\hline 29 & $J P G$ & 600 & 399 & 24 & 72 \\
\hline 30 & SVG & - & - & - & - \\
\hline 31 & SVG & NA & NA & $\mathrm{NA}$ & NA \\
\hline 32 & SVG & - & - & - & - \\
\hline 33 & SVG & - & - & - & - \\
\hline 34 & SVG & - & - & - & - \\
\hline 35 & SVG & - & - & - & - \\
\hline
\end{tabular}


Tabla 9. Buenas prácticas y alternativas textuales

\begin{tabular}{|c|c|c|c|c|c|c|c|}
\hline ID & Título & Ejes & Abreviaturas & $\begin{array}{l}\text { Fuente de datos / } \\
\text { Fecha de la fuente / } \\
\text { Enlace a la fuente }\end{array}$ & $\begin{array}{l}\text { Versión impresión / } \\
\text { Versión impresión cortada / } \\
\text { Versión impresión con } \\
\text { solapamientos }\end{array}$ & $\begin{array}{l}\text { Texto alterna- } \\
\text { tivo corto }\end{array}$ & $\begin{array}{c}\text { Descripción } \\
\text { larga }\end{array}$ \\
\hline 1 & $\begin{array}{l}\text { Con título, pero } \\
\text { no breve ni } \\
\text { descriptivo }\end{array}$ & NA & NA & $\begin{array}{l}\text { Con fuente de datos. } \\
\text { No } \\
\text { No }\end{array}$ & $\begin{array}{l}\text { Sí } \\
\text { No } \\
\text { No }\end{array}$ & $\begin{array}{l}\text { Con texto al- } \\
\text { ternativo pero } \\
\text { inadecuado. }\end{array}$ & No \\
\hline 2 & $\begin{array}{l}\text { Con título, pero } \\
\text { no breve ni } \\
\text { descriptivo }\end{array}$ & $\begin{array}{l}\text { Con ejes, } \\
\text { pero sin } \\
\text { indicar las } \\
\text { unidades de } \\
\text { medida. }\end{array}$ & NA & $\begin{array}{l}\text { Con fuente de datos. } \\
\qquad \text { No } \\
\text { Sí }\end{array}$ & $\begin{array}{l}\text { Sí } \\
\text { No } \\
\text { No }\end{array}$ & $\begin{array}{l}\text { Con texto al- } \\
\text { ternativo pero } \\
\text { inadecuado. }\end{array}$ & No \\
\hline 3 & $\begin{array}{l}\text { Con título, pero } \\
\text { no breve ni } \\
\text { descriptivo }\end{array}$ & $\begin{array}{l}\text { Con ejes, } \\
\text { pero sin } \\
\text { etiquetar. }\end{array}$ & NA & $\begin{array}{l}\text { Con fuente de datos. } \\
\text { Sí } \\
\text { No }\end{array}$ & $\begin{array}{l}\text { Sí } \\
\text { No } \\
\text { No }\end{array}$ & No & No \\
\hline 4 & Con título & Con ejes & NA & $\begin{array}{l}\text { Con fuente de datos. } \\
\qquad \begin{array}{c}\text { No } \\
\text { No }\end{array}\end{array}$ & $\begin{array}{l}\text { Sí } \\
\text { Sí } \\
\text { No }\end{array}$ & $\begin{array}{l}\text { Con texto al- } \\
\text { ternativo pero } \\
\text { inadecuado. }\end{array}$ & No \\
\hline 5 & Con título & Con ejes & $\begin{array}{l}\text { Sin desarro- } \\
\text { llar, pero de } \\
\text { uso común. }\end{array}$ & $\begin{array}{l}\text { Con fuente de datos. } \\
\qquad \begin{array}{c}\text { No } \\
\text { No }\end{array}\end{array}$ & $\begin{array}{l}\text { Sí } \\
\text { No } \\
\text { No }\end{array}$ & $\begin{array}{l}\text { Con texto al- } \\
\text { ternativo pero } \\
\text { inadecuado. }\end{array}$ & No \\
\hline 6 & Con título & $\begin{array}{c}\text { Con ejes, } \\
\text { pero sin } \\
\text { indicar las } \\
\text { unidades de } \\
\text { medida. }\end{array}$ & NA & $\begin{array}{l}\text { Con fuente de datos. } \\
\qquad \begin{array}{c}\text { No } \\
\text { No }\end{array}\end{array}$ & $\begin{array}{l}\text { Sí } \\
\text { Sí } \\
\text { Sí }\end{array}$ & No & No \\
\hline 7 & Con título & $\begin{array}{l}\text { Con ejes, } \\
\text { pero sin } \\
\text { etiquetar. }\end{array}$ & NA & $\begin{array}{c}\text { Sin fuente de datos. } \\
\text { No } \\
\text { No }\end{array}$ & $\begin{array}{l}\text { Sí } \\
\text { No } \\
\text { No }\end{array}$ & No & No \\
\hline 8 & Con título & Con ejes & NA & $\begin{array}{l}\text { Con fuente de datos. } \\
\qquad \begin{array}{c}\text { No } \\
\text { No }\end{array}\end{array}$ & $\begin{array}{l}\text { Sí } \\
\text { No } \\
\text { No }\end{array}$ & No & No \\
\hline 9 & Con título & Con ejes & $\begin{array}{l}\text { Sin desarro- } \\
\text { llar, pero de } \\
\text { uso común. }\end{array}$ & $\begin{array}{c}\text { Con fuente de datos. } \\
\text { Sí } \\
\text { No }\end{array}$ & $\begin{array}{l}\text { Sí } \\
\text { No } \\
\text { No }\end{array}$ & No & No \\
\hline 10 & Con título & $\begin{array}{c}\text { Con ejes, } \\
\text { pero sin } \\
\text { indicar las } \\
\text { unidades de } \\
\text { medida. }\end{array}$ & NA & $\begin{array}{c}\text { Con fuente de datos. } \\
\text { Sí } \\
\text { No }\end{array}$ & $\begin{array}{l}\text { Sí } \\
\text { Sí } \\
\text { No }\end{array}$ & No & No \\
\hline 11 & Con título & NA & $\begin{array}{l}\text { Sin desarro- } \\
\text { llar, pero de } \\
\text { uso común. }\end{array}$ & $\begin{array}{c}\text { Con fuente de datos. } \\
\text { Sí } \\
\text { No }\end{array}$ & $\begin{array}{l}\text { Sí } \\
\text { Sí } \\
\text { No }\end{array}$ & $\begin{array}{l}\text { Con texto } \\
\text { alternativo } \\
\text { corto. }\end{array}$ & No \\
\hline 12 & Con título & NA & NA & $\begin{array}{l}\text { Con fuente de datos. } \\
\text { No } \\
\text { No }\end{array}$ & $\begin{array}{l}\text { Sí } \\
\text { No } \\
\text { No }\end{array}$ & No & No \\
\hline 13 & $\begin{array}{c}\text { Con título, pero } \\
\text { no breve ni } \\
\text { descriptivo }\end{array}$ & $\begin{array}{l}\text { Con ejes, } \\
\text { pero sin } \\
\text { etiquetar. }\end{array}$ & NA & $\begin{array}{l}\text { NA } \\
\text { NA } \\
\text { NA }\end{array}$ & $\begin{array}{l}\text { Sí } \\
\text { Sí } \\
\text { No }\end{array}$ & No & No \\
\hline 14 & $\begin{array}{c}\text { Con título, pero } \\
\text { no breve ni } \\
\text { descriptivo }\end{array}$ & Con ejes & NA & $\begin{array}{l}\text { Con fuente de datos. } \\
\qquad \begin{array}{c}\text { No } \\
\text { No }\end{array}\end{array}$ & $\begin{array}{l}\text { Sí } \\
\text { No } \\
\text { Sí }\end{array}$ & $\begin{array}{l}\text { Con texto al- } \\
\text { ternativo pero } \\
\text { inadecuado. }\end{array}$ & No \\
\hline 15 & Con título & Con ejes & NA & $\begin{array}{c}\text { Con fuente de datos. } \\
\text { Sí } \\
\text { No }\end{array}$ & $\begin{array}{l}\text { Sí } \\
\text { Sí } \\
\text { No }\end{array}$ & No & No \\
\hline 16 & Con título & Con ejes & $\begin{array}{l}\text { Sin desarro- } \\
\text { llar. }\end{array}$ & $\begin{array}{l}\text { Con fuente de datos. } \\
\text { No } \\
\text { No }\end{array}$ & $\begin{array}{l}\text { Sí } \\
\text { No } \\
\text { No }\end{array}$ & No & No \\
\hline 17 & $\begin{array}{c}\text { Con título, pero } \\
\text { no breve ni } \\
\text { descriptivo }\end{array}$ & Con ejes & NA & $\begin{array}{l}\text { Con fuente de datos. } \\
\text { No } \\
\text { No }\end{array}$ & $\begin{array}{l}\text { Sí } \\
\text { No } \\
\text { No }\end{array}$ & No & No \\
\hline 18 & Sin título & $\begin{array}{l}\text { Con ejes } \\
\text { pero texto } \\
\text { inclinado. }\end{array}$ & $\begin{array}{l}\text { Sin desarro- } \\
\text { llar, pero de } \\
\text { uso común. }\end{array}$ & $\begin{array}{l}\text { Sin fuente de datos. } \\
\text { No } \\
\text { No }\end{array}$ & $\begin{array}{l}\text { Sí } \\
\text { No } \\
\text { No }\end{array}$ & $\begin{array}{l}\text { Con texto } \\
\text { alternativo } \\
\text { corto. }\end{array}$ & No \\
\hline
\end{tabular}




\begin{tabular}{|c|c|c|c|c|c|c|c|}
\hline ID & Título & Ejes & Abreviaturas & $\begin{array}{l}\text { Fuente de datos / } \\
\text { Fecha de la fuente / } \\
\text { Enlace a la fuente }\end{array}$ & $\begin{array}{l}\text { Versión impresión / } \\
\text { Versión impresión cortada / } \\
\text { Versión impresión con } \\
\text { solapamientos }\end{array}$ & $\begin{array}{l}\text { Texto alterna- } \\
\text { tivo corto }\end{array}$ & $\begin{array}{c}\text { Descripción } \\
\text { larga }\end{array}$ \\
\hline 19 & Con título & NP & NA & $\begin{array}{l}\text { Con fuente de datos. } \\
\text { No } \\
\text { No }\end{array}$ & $\begin{array}{l}\text { Sí } \\
\text { No } \\
\text { No }\end{array}$ & No & No \\
\hline 20 & Con título & Con ejes & NA & $\begin{array}{c}\text { Con fuente de datos. } \\
\text { Sí } \\
\text { No }\end{array}$ & $\begin{array}{l}\text { Sí } \\
\text { No } \\
\text { No }\end{array}$ & No & Sí \\
\hline 21 & Con título & $\begin{array}{l}\text { Con ejes } \\
\text { pero texto } \\
\text { inclinado. }\end{array}$ & $\begin{array}{l}\text { Sin desarro- } \\
\text { llar, pero de } \\
\text { uso } \\
\text { común. }\end{array}$ & $\begin{array}{l}\text { Sin fuente de datos. } \\
\text { No } \\
\text { No }\end{array}$ & $\begin{array}{l}\text { Sí } \\
\text { No } \\
\text { Sí }\end{array}$ & $\begin{array}{l}\text { Con texto } \\
\text { alternativo } \\
\text { corto. }\end{array}$ & No \\
\hline 22 & Con título & NA & $\begin{array}{l}\text { Sin desarro- } \\
\text { llar, pero de } \\
\text { uso común. }\end{array}$ & $\begin{array}{l}\text { Sin fuente de datos. } \\
\text { No } \\
\text { No }\end{array}$ & $\begin{array}{l}\text { Sí } \\
\text { No } \\
\text { Sí }\end{array}$ & $\begin{array}{l}\text { Con texto } \\
\text { alternativo } \\
\text { corto. }\end{array}$ & No \\
\hline 23 & Con título & NP & NA & $\begin{array}{l}\text { Con fuente de datos. } \\
\qquad \begin{array}{c}\text { No } \\
\text { No }\end{array}\end{array}$ & $\begin{array}{l}\text { Sí } \\
\text { Sí } \\
\text { No }\end{array}$ & No & No \\
\hline 24 & Sin título & NA & NA & $\begin{array}{l}\text { Sin fuente de datos. } \\
\text { No } \\
\text { No }\end{array}$ & $\begin{array}{l}\text { Sí } \\
\text { No } \\
\text { Sí }\end{array}$ & $\begin{array}{l}\text { Con texto } \\
\text { alternativo } \\
\text { corto. }\end{array}$ & No \\
\hline 25 & Con título & NA & $\begin{array}{l}\text { Desarrolla- } \\
\text { das. }\end{array}$ & $\begin{array}{l}\text { Con fuente de datos. } \\
\qquad \begin{array}{c}\text { No } \\
\text { No }\end{array}\end{array}$ & $\begin{array}{l}\text { Sí } \\
\text { No } \\
\text { Sí }\end{array}$ & $\begin{array}{l}\text { Con texto al- } \\
\text { ternativo pero } \\
\text { inadecuado. }\end{array}$ & No \\
\hline 26 & $\begin{array}{l}\text { Con título, pero } \\
\text { no breve ni } \\
\text { descriptivo }\end{array}$ & $\begin{array}{l}\text { Con ejes, } \\
\text { pero sín } \\
\text { indicar las } \\
\text { unidades de } \\
\text { medida. }\end{array}$ & $\begin{array}{l}\text { Sin desarro- } \\
\text { llar, pero de } \\
\text { uso común. }\end{array}$ & $\begin{array}{c}\text { Con fuente de datos. } \\
\qquad \text { Sí } \\
\text { No }\end{array}$ & $\begin{array}{l}\text { No } \\
\text { NA } \\
\text { NA }\end{array}$ & No & No \\
\hline 27 & Con título & Con ejes & NA & $\begin{array}{l}\text { Con fuente de datos. } \\
\qquad \begin{array}{c}\text { No } \\
\text { No }\end{array}\end{array}$ & $\begin{array}{l}\text { No } \\
\text { NA } \\
\text { NA }\end{array}$ & No & No \\
\hline 28 & $\begin{array}{c}\text { Con título, pero } \\
\text { no breve ni } \\
\text { descriptivo }\end{array}$ & $\begin{array}{l}\text { Con ejes, } \\
\text { pero sin } \\
\text { etiquetar. }\end{array}$ & NA & $\begin{array}{l}\text { Con fuente de datos. } \\
\qquad \begin{array}{c}\text { No } \\
\text { No }\end{array}\end{array}$ & $\begin{array}{l}\text { No } \\
\text { NA } \\
\text { NA }\end{array}$ & No & No \\
\hline 29 & Con título & $\begin{array}{l}\text { Con ejes, } \\
\text { pero sin } \\
\text { indicar las } \\
\text { unidades de } \\
\text { medida. }\end{array}$ & NA & $\begin{array}{l}\text { Con fuente de datos. } \\
\qquad \begin{array}{c}\text { No } \\
\text { No }\end{array}\end{array}$ & $\begin{array}{l}\text { No } \\
\text { NA } \\
\text { NA }\end{array}$ & No & No \\
\hline 30 & Con título & Con ejes & NA & $\begin{array}{l}\text { Con fuente de datos. } \\
\text { No } \\
\text { No }\end{array}$ & $\begin{array}{l}\text { No } \\
\text { NA } \\
\text { NA }\end{array}$ & No & No \\
\hline 31 & Con título & Con ejes & $\begin{array}{l}\text { Sin desarro- } \\
\text { Ilar. }\end{array}$ & $\begin{array}{l}\text { Con fuente de datos. } \\
\qquad \begin{array}{c}\text { No } \\
\text { No }\end{array}\end{array}$ & $\begin{array}{l}\text { No } \\
\text { NA } \\
\text { NA }\end{array}$ & No & No \\
\hline 32 & Con título & Con ejes & NA & $\begin{array}{l}\text { Con fuente de datos. } \\
\qquad \begin{array}{c}\text { No } \\
\text { No }\end{array}\end{array}$ & $\begin{array}{l}\text { No } \\
\text { NA } \\
\text { NA }\end{array}$ & No & No \\
\hline 33 & Sin título & Con ejes & NA & $\begin{array}{l}\text { Con fuente de datos. } \\
\text { No } \\
\text { No }\end{array}$ & $\begin{array}{l}\text { No } \\
\text { NA } \\
\text { NA }\end{array}$ & No & No \\
\hline 34 & Con título & Con ejes & $\begin{array}{l}\text { Sin desarro- } \\
\text { llar, pero de } \\
\text { uso común. }\end{array}$ & $\begin{array}{l}\text { Con fuente de datos. } \\
\text { No } \\
\text { No }\end{array}$ & $\begin{array}{l}\text { No } \\
\text { NA } \\
\text { NA }\end{array}$ & No & No \\
\hline 35 & Con título & Con ejes & NA & $\begin{array}{l}\text { Con fuente de datos. } \\
\text { No } \\
\text { No }\end{array}$ & $\begin{array}{l}\text { No } \\
\text { NA } \\
\text { NA }\end{array}$ & No & No \\
\hline
\end{tabular}

Excepto 3, todos los gráficos analizados cuentan con un título, si bien en un pequeño porcentaje de ellos (8 de 35) no se trata de un título breve y descriptivo que ayude al lector a identificarlo y diferenciarlo del resto de gráficos incluidos en la misma página. 
Por lo que respecta al uso de ejes, todos los gráficos que los precisan cuentan con ellos, si bien en 4 casos se encuentran sin etiquetar. Por otro lado, en 5 de los gráficos no se indican las unidades de medida empleadas. Finalmente, en 2 casos se muestran sus etiquetas con el texto inclinado, lo que dificulta su lectura.

De los 35 gráficos, sólo 2 muestran las abreviaturas sin desarrollar, en el resto de los casos o no se utilizan abreviaturas o el hecho de no desarrollarlas no supone un problema por tratarse de abreviaturas suficientemente estandarizadas y familiares para el lector.

La gran mayoría de los gráficos analizados incluyen la fuente de datos utilizada para crear la visualización (29 de 35), si bien son pocos los que aportan la fecha (7 de 35) o enlazan a la fuente (1 de 35). Este hecho disminuye la capacidad del lector de acudir a los datos tabulares tanto para fines de accesibilidad como de validación de los datos presentados.

Por lo que respecta a la versión para impresión, ninguno de los medios analizados cuenta con una hoja de estilos específica para este medio. En los dos medios internacionales, tanto The guardian como The New York times han optado por no incluir estas imágenes en la versión impresa. En el resto de medios, encontramos 7 casos en los cuales el gráfico aparece cortado entre dos páginas, 6 en los que algún otro elemento se solapa con el gráfico impidiendo total o parcialmente su lectura y 5 casos en los que la calidad de la imagen es insuficiente para una lectura satisfactoria.

Ninguno de los gráficos analizados cuenta con un pie de imagen, limitándose a usar su espacio para incluir la fuente en aquellos casos en los que se proporciona información sobre ella. Este hecho quizá no es muy grave en gráficos de prensa por su sencillez, pero puede alcanzar mayor peso en gráficos educativos o de artículos científicos en los que la validez estadística y otros datos complementarios tienen mayor relevancia.

La mayoría de los gráficos analizados no cuentan con ninguna alternativa de texto (alternativa corta o descripción larga). En 24 de los 35 gráficos no consta ningún tipo de alternativa textual corta. En las imágenes en formato de mapa de bits, nos referimos al atributo alt que, o bien no se utiliza, o se encuentra vacío. Este atributo, además de encontrarse entre los criterios de conformidad para alcanzar el nivel de accesibilidad mínimo exigido por la legislación española, también otorga beneficios a nivel de posicionamiento web al ser un contenido indexado por los buscadores (Ferraz, 2017). Por lo que respecta a las imágenes en formato SVG, a pesar de ser totalmente compatibles y existir una especificación concreta del World Wide Web Consortium (2018b) para su descripción con el estándar WAI-ARIA (World Wide Web Consortium, 2017), tampoco encontramos estos atributos para describir el contenido del gráfico, ni de cada uno de sus elementos. Sólo 11 de los 35 gráficos cuentan con un texto alternativo corto; no obstante, 6 de ellos no son adecuados para identificar el gráfico.

Todos los gráficos analizados, excepto uno, carecen de una alternativa en forma de descripción larga. La excepción es un gráfico que se complementa con un buscador que muestra la información del gráfico en formato tabla. Las descripciones largas son imprescindibles para que ciertos perfiles de discapacidad visual como las personas ciegas, puedan acceder al contenido de imágenes complejas como son los gráficos estadísticos. Son útiles para las personas que presentan un resto de visión muy bajo e interactúan con lectores de pantalla, y en los gráficos en formato de imagen de mapa de bits facilita a todos los perfiles el poder buscar un valor concreto de los visualizados en el gráfico. Si bien en alguno de los casos analizados, podríamos entender que la descripción larga es el mismo artículo, en ninguno podemos afirmar que este suponga una descripción completa y pormenorizada de toda la información que contiene el gráfico.

Tabla 10. Contraste, legibilidad y características adicionales

\begin{tabular}{|c|c|c|c|c|c|c|c|}
\hline ID & Contraste textual & $\begin{array}{l}\text { Contraste no } \\
\text { textual }\end{array}$ & $\begin{array}{l}\text { Fuente tipográ- } \\
\text { fica }\end{array}$ & $\begin{array}{c}\text { Elementos que obsta- } \\
\text { culización la visión del } \\
\text { gráfico }\end{array}$ & Zoom & $\begin{array}{l}\text { Foco } \\
\text { visible }\end{array}$ & $\begin{array}{c}\text { Accesible } \\
\text { por } \\
\text { teclado }\end{array}$ \\
\hline 1 & $\begin{array}{l}\text { Contraste } \\
\text { suficiente }(4,5: 1 \\
\text { o más) }\end{array}$ & $\begin{array}{l}\text { Contraste insufi- } \\
\text { ciente }(2,43: 1)\end{array}$ & $\begin{array}{l}\text { Tamaño de fuen- } \\
\text { te adecuado. }\end{array}$ & Marca de agua & $\begin{array}{l}\text { El gráfico se puede } \\
\text { redimensionar, pero la } \\
\text { imagen pierde calidad. }\end{array}$ & NA & NA \\
\hline 2 & $\begin{array}{l}\text { Contraste } \\
\text { suficiente (4,5:1 } \\
\text { o más) }\end{array}$ & $\begin{array}{l}\text { Contraste sufi- } \\
\text { ciente (3:1 o más) }\end{array}$ & $\begin{array}{l}\text { Tamaño de fuen- } \\
\text { te pequeño }\end{array}$ & $\begin{array}{l}\text { Sin elementos que } \\
\text { obstaculizan la visión } \\
\text { del gráfico. }\end{array}$ & $\begin{array}{l}\text { El gráfico se puede } \\
\text { redimensionar. }\end{array}$ & NA & NA \\
\hline 3 & $\begin{array}{l}\text { Contraste } \\
\text { suficiente (4,5:1 } \\
\text { o más) }\end{array}$ & $\begin{array}{l}\text { Contraste insufi- } \\
\text { ciente }(1,99: 1)\end{array}$ & $\begin{array}{l}\text { Tamaño de fuen- } \\
\text { te pequeño }\end{array}$ & $\begin{array}{l}\text { Sin elementos que } \\
\text { obstaculizan la visión } \\
\text { del gráfico. }\end{array}$ & $\begin{array}{l}\text { El gráfico se puede } \\
\text { redimensionar. }\end{array}$ & No & No \\
\hline 4 & $\begin{array}{l}\text { Contraste } \\
\text { suficiente }(4,5: 1 \\
\text { o más) }\end{array}$ & $\begin{array}{l}\text { Contraste insufi- } \\
\text { ciente }(1,79: 1)\end{array}$ & $\begin{array}{l}\text { Tamaño de fuen- } \\
\text { te adecuado. }\end{array}$ & $\begin{array}{l}\text { Sin elementos que } \\
\text { obstaculizan la visión } \\
\text { del gráfico. }\end{array}$ & $\begin{array}{l}\text { El gráfico se puede } \\
\text { redimensionar. }\end{array}$ & NA & NA \\
\hline 5 & $\begin{array}{l}\text { Contraste insufi- } \\
\text { ciente }(1,92: 1)\end{array}$ & $\begin{array}{l}\text { Contraste insufi- } \\
\text { ciente }(2,76: 1)\end{array}$ & $\begin{array}{l}\text { Tamaño de fuen- } \\
\text { te pequeño }\end{array}$ & $\begin{array}{l}\text { Sin elementos que } \\
\text { obstaculizan la visión } \\
\text { del gráfico. }\end{array}$ & $\begin{array}{l}\text { El gráfico se puede } \\
\text { redimensionar. }\end{array}$ & NA & NA \\
\hline 6 & $\begin{array}{l}\text { Contraste } \\
\text { suficiente }(4,5: 1 \\
\text { o más) }\end{array}$ & $\begin{array}{l}\text { Contraste insufi- } \\
\text { ciente (indicar) }\end{array}$ & $\begin{array}{l}\text { Tamaño de fuen- } \\
\text { te pequeño }\end{array}$ & $\begin{array}{l}\text { Sin elementos que } \\
\text { obstaculizan la visión } \\
\text { del gráfico. }\end{array}$ & $\begin{array}{l}\text { El gráfico se puede } \\
\text { redimensionar. }\end{array}$ & NA & NA \\
\hline
\end{tabular}




\begin{tabular}{|c|c|c|c|c|c|c|c|}
\hline ID & Contraste textual & $\begin{array}{c}\text { Contraste no } \\
\text { textual }\end{array}$ & $\begin{array}{l}\text { Fuente tipográ- } \\
\text { fica }\end{array}$ & $\begin{array}{l}\text { Elementos que obsta- } \\
\text { culización la visión del } \\
\text { gráfico }\end{array}$ & Zoom & $\begin{array}{l}\text { Foco } \\
\text { visible }\end{array}$ & $\begin{array}{l}\text { Accesible } \\
\text { por } \\
\text { teclado }\end{array}$ \\
\hline 7 & $\begin{array}{l}\text { Contraste } \\
\text { suficiente }(4,5: 1 \\
\text { o más) }\end{array}$ & $\begin{array}{l}\text { Contraste sufi- } \\
\text { ciente (3:1 o más) }\end{array}$ & $\begin{array}{l}\text { Tamaño de fuen- } \\
\text { te adecuado. }\end{array}$ & Banners publicitarios & $\begin{array}{l}\text { El gráfico se puede } \\
\text { redimensionar, pero la } \\
\text { imagen pierde calidad. }\end{array}$ & NA & NA \\
\hline 8 & $\begin{array}{l}\text { Contraste } \\
\text { suficiente (4,5:1 } \\
\text { o más) }\end{array}$ & $\begin{array}{l}\text { Contraste sufi- } \\
\text { ciente (3:1 o más) }\end{array}$ & $\begin{array}{l}\text { Tamaño de fuen- } \\
\text { te pequeño }\end{array}$ & $\begin{array}{l}\text { Sin elementos que } \\
\text { obstaculizan la visión } \\
\text { del gráfico. }\end{array}$ & $\begin{array}{l}\text { El gráfico se puede } \\
\text { redimensionar. }\end{array}$ & NA & NA \\
\hline 9 & $\begin{array}{l}\text { Contraste } \\
\text { suficiente }(4,5: 1 \\
\text { o más) }\end{array}$ & $\begin{array}{l}\text { Contraste insufi- } \\
\text { ciente }(1,72: 1)\end{array}$ & $\begin{array}{l}\text { Tamaño de fuen- } \\
\text { te pequeño }\end{array}$ & $\begin{array}{l}\text { Sin elementos que } \\
\text { obstaculizan la visión } \\
\text { del gráfico. }\end{array}$ & $\begin{array}{l}\text { El gráfico se puede } \\
\text { redimensionar. }\end{array}$ & NA & NA \\
\hline 10 & $\begin{array}{l}\text { Contraste insufi- } \\
\text { ciente }(3,02: 1)\end{array}$ & $\begin{array}{l}\text { Contraste insufi- } \\
\text { ciente }(3,02: 1)\end{array}$ & $\begin{array}{l}\text { Tamaño de fuen- } \\
\text { te pequeño }\end{array}$ & Banners publicitarios & $\begin{array}{l}\text { El gráfico se puede } \\
\text { redimensionar. }\end{array}$ & Sí & No \\
\hline 11 & $\begin{array}{l}\text { Contraste } \\
\text { suficiente }(4,5: 1 \\
\text { o más) }\end{array}$ & $\begin{array}{l}\text { Contraste sufi- } \\
\text { ciente (3:1 o más) }\end{array}$ & $\begin{array}{l}\text { Tamaño de fuen- } \\
\text { te pequeño }\end{array}$ & $\begin{array}{l}\text { Sin elementos que } \\
\text { obstaculizan la visión } \\
\text { del gráfico. }\end{array}$ & $\begin{array}{l}\text { El gráfico se puede } \\
\text { redimensionar, pero la } \\
\text { imagen pierde calidad. }\end{array}$ & NA & NA \\
\hline 12 & $\begin{array}{l}\text { Contraste } \\
\text { suficiente ( } 4,5: 1 \\
\text { o más) }\end{array}$ & $\begin{array}{l}\text { Contraste insufi- } \\
\text { ciente }(1,33: 1)\end{array}$ & $\begin{array}{l}\text { Tamaño de fuen- } \\
\text { te pequeño }\end{array}$ & Banners publicitarios & $\begin{array}{l}\text { El gráfico se puede } \\
\text { redimensionar, pero la } \\
\text { imagen pierde calidad. }\end{array}$ & NA & NA \\
\hline 13 & $\begin{array}{l}\text { Contraste insufi- } \\
\text { ciente }(2,46: 1)\end{array}$ & $\begin{array}{l}\text { Contraste insufi- } \\
\text { ciente }(2,46: 1)\end{array}$ & $\begin{array}{l}\text { Tamaño de fuen- } \\
\text { te pequeño }\end{array}$ & $\begin{array}{l}\text { Sin elementos que } \\
\text { obstaculizan la visión } \\
\text { del gráfico. }\end{array}$ & $\begin{array}{l}\text { El gráfico se puede } \\
\text { redimensionar, pero } \\
\text { se solapa con otros } \\
\text { elementos. }\end{array}$ & Sí & No \\
\hline 14 & $\begin{array}{l}\text { Contraste } \\
\text { suficiente (4,5:1 } \\
\text { o más) }\end{array}$ & $\begin{array}{l}\text { Contraste insufi- } \\
\text { ciente }(2,53: 1)\end{array}$ & $\begin{array}{l}\text { Tamaño de fuen- } \\
\text { te pequeño }\end{array}$ & Banners publicitarios & $\begin{array}{l}\text { El gráfico se puede } \\
\text { redimensionar, pero } \\
\text { se solapa con otros } \\
\text { elementos. }\end{array}$ & NA & NA \\
\hline 15 & $\begin{array}{l}\text { Contraste } \\
\text { suficiente ( } 4,5: 1 \\
\text { o más) }\end{array}$ & $\begin{array}{l}\text { Contraste insufi- } \\
\text { ciente }(1,62: 1)\end{array}$ & $\begin{array}{l}\text { Tamaño de fuen- } \\
\text { te adecuado. }\end{array}$ & Banners publicitarios & $\begin{array}{l}\text { El gráfico se puede } \\
\text { redimensionar. }\end{array}$ & NA & NA \\
\hline 16 & $\begin{array}{l}\text { Contraste } \\
\text { suficiente (4,5:1 } \\
\text { o más) }\end{array}$ & $\begin{array}{l}\text { Contraste sufi- } \\
\text { ciente (3:1 o más) }\end{array}$ & $\begin{array}{l}\text { Tamaño de fuen- } \\
\text { te pequeño }\end{array}$ & $\begin{array}{l}\text { Sin elementos que } \\
\text { obstaculizan la visión } \\
\text { del gráfico. }\end{array}$ & $\begin{array}{l}\text { El gráfico se puede } \\
\text { redimensionar. }\end{array}$ & NA & NA \\
\hline 17 & $\begin{array}{l}\text { Contraste } \\
\text { suficiente }(4,5: 1 \\
\text { o más) }\end{array}$ & $\begin{array}{l}\text { Contraste insufi- } \\
\text { ciente }(1,71: 1)\end{array}$ & $\begin{array}{l}\text { Tamaño de fuen- } \\
\text { te pequeño }\end{array}$ & Banners publicitarios & $\begin{array}{l}\text { El gráfico se puede } \\
\text { redimensionar. }\end{array}$ & NA & NA \\
\hline 18 & $\begin{array}{l}\text { Contraste } \\
\text { suficiente (4,5:1 } \\
\text { o más) }\end{array}$ & $\begin{array}{l}\text { Contraste insufi- } \\
\text { ciente }(1,7: 1)\end{array}$ & $\begin{array}{l}\text { Tamaño de fuen- } \\
\text { te pequeño }\end{array}$ & $\begin{array}{l}\text { Sin elementos que } \\
\text { obstaculizan la visión } \\
\text { del gráfico. }\end{array}$ & $\begin{array}{l}\text { El gráfico se puede } \\
\text { redimensionar, pero la } \\
\text { imagen pierde calidad. }\end{array}$ & NA & NA \\
\hline 19 & $\begin{array}{l}\text { Contraste } \\
\text { suficiente (4,5:1 } \\
\text { o más) }\end{array}$ & $\begin{array}{l}\text { Contraste insufi- } \\
\text { ciente }(1,36: 1)\end{array}$ & $\begin{array}{l}\text { Tamaño de fuen- } \\
\text { te pequeño }\end{array}$ & $\begin{array}{l}\text { Sin elementos que } \\
\text { obstaculizan la visión } \\
\text { del gráfico. }\end{array}$ & $\begin{array}{l}\text { El gráfico se puede } \\
\text { redimensionar, pero la } \\
\text { imagen pierde calidad. }\end{array}$ & NA & NA \\
\hline 20 & $\begin{array}{l}\text { Contraste } \\
\text { suficiente (4,5:1 } \\
\text { o más) }\end{array}$ & $\begin{array}{l}\text { Contraste sufi- } \\
\text { ciente (3:1 o más) }\end{array}$ & $\begin{array}{l}\text { Tamaño de fuen- } \\
\text { te pequeño }\end{array}$ & $\begin{array}{l}\text { Sin elementos que } \\
\text { obstaculizan la visión } \\
\text { del gráfico. }\end{array}$ & $\begin{array}{l}\text { El gráfico se puede } \\
\text { redimensionar. }\end{array}$ & NA & NA \\
\hline 21 & $\begin{array}{l}\text { Contraste } \\
\text { suficiente ( } 4,5: 1 \\
\text { o más) }\end{array}$ & $\begin{array}{l}\text { Contraste insufi- } \\
\text { ciente }(1,23: 1)\end{array}$ & $\begin{array}{l}\text { Tamaño de fuen- } \\
\text { te pequeño }\end{array}$ & Banners publicitarios & $\begin{array}{l}\text { El gráfico se puede } \\
\text { redimensionar. }\end{array}$ & NA & NA \\
\hline 22 & $\begin{array}{l}\text { Contraste } \\
\text { suficiente (4,5:1 } \\
\text { o más) }\end{array}$ & $\begin{array}{l}\text { Contraste insufi- } \\
\text { ciente }(1,02: 1)\end{array}$ & $\begin{array}{l}\text { Tamaño de fuen- } \\
\text { te pequeño }\end{array}$ & Banners publicitarios & $\begin{array}{l}\text { El gráfico se puede } \\
\text { redimensionar, pero } \\
\text { se solapa con otros } \\
\text { elementos. }\end{array}$ & NA & NA \\
\hline 23 & $\begin{array}{l}\text { Contraste } \\
\text { suficiente (4,5:1 } \\
\text { o más) }\end{array}$ & $\begin{array}{l}\text { Contraste insufi- } \\
\text { ciente }(1,76: 1)\end{array}$ & $\begin{array}{l}\text { Tamaño de fuen- } \\
\text { te pequeño }\end{array}$ & $\begin{array}{l}\text { Sin elementos que } \\
\text { obstaculizan la visión } \\
\text { del gráfico. }\end{array}$ & $\begin{array}{l}\text { El gráfico se puede } \\
\text { redimensionar, pero } \\
\text { se solapa con otros } \\
\text { elementos. }\end{array}$ & No & No \\
\hline 24 & $\begin{array}{l}\text { Contraste } \\
\text { suficiente (4,5:1 } \\
\text { o más) }\end{array}$ & $\begin{array}{l}\text { Contraste insufi- } \\
\text { ciente }(1,23: 1)\end{array}$ & $\begin{array}{l}\text { Tamaño de fuen- } \\
\text { te adecuado. }\end{array}$ & Banners publicitarios & $\begin{array}{l}\text { El gráfico se puede } \\
\text { redimensionar, pero la } \\
\text { imagen pierde calidad. }\end{array}$ & NA & NA \\
\hline 25 & $\begin{array}{l}\text { Contraste insufi- } \\
\text { ciente }(2,52: 1)\end{array}$ & $\begin{array}{l}\text { Contraste insufi- } \\
\text { ciente }(1,09: 1)\end{array}$ & $\begin{array}{l}\text { Tamaño de fuen- } \\
\text { te adecuado. }\end{array}$ & Banners publicitarios & $\begin{array}{l}\text { El gráfico se puede } \\
\text { redimensionar, pero } \\
\text { se solapa con otros } \\
\text { elementos. }\end{array}$ & NA & NA \\
\hline
\end{tabular}




\begin{tabular}{|c|c|c|c|c|c|c|c|}
\hline ID & Contraste textual & $\begin{array}{c}\text { Contraste no } \\
\text { textual }\end{array}$ & $\begin{array}{l}\text { Fuente tipográ- } \\
\text { fica }\end{array}$ & $\begin{array}{c}\text { Elementos que obsta- } \\
\text { culización la visión del } \\
\text { gráfico }\end{array}$ & Zoom & $\begin{array}{l}\text { Foco } \\
\text { visible }\end{array}$ & $\begin{array}{l}\text { Accesible } \\
\text { por } \\
\text { teclado }\end{array}$ \\
\hline 26 & $\begin{array}{l}\text { Contraste } \\
\text { suficiente (4,5:1 } \\
\text { o más) }\end{array}$ & $\begin{array}{l}\text { Contraste sufi- } \\
\text { ciente (3:1 o más) }\end{array}$ & $\begin{array}{l}\text { Tamaño de fuen- } \\
\text { te pequeño }\end{array}$ & $\begin{array}{l}\text { Sin elementos que } \\
\text { obstaculizan la visión } \\
\text { del gráfico. }\end{array}$ & $\begin{array}{l}\text { El gráfico se puede } \\
\text { redimensionar, pero } \\
\text { se solapa con otros } \\
\text { elementos. }\end{array}$ & NA & NA \\
\hline 27 & $\begin{array}{l}\text { Contraste } \\
\text { suficiente (4,5:1 } \\
\text { o más) }\end{array}$ & $\begin{array}{l}\text { Contraste sufi- } \\
\text { ciente (3:1 o más) }\end{array}$ & $\begin{array}{l}\text { Tamaño de fuen- } \\
\text { te pequeño }\end{array}$ & $\begin{array}{l}\text { Sin elementos que } \\
\text { obstaculizan la visión } \\
\text { del gráfico. }\end{array}$ & $\begin{array}{l}\text { El gráfico se puede } \\
\text { redimensionar. }\end{array}$ & No & No \\
\hline 28 & $\begin{array}{l}\text { Contraste } \\
\text { suficiente }(4,5: 1 \\
\text { o más) }\end{array}$ & $\begin{array}{l}\text { Contraste insufi- } \\
\text { ciente }(2,32: 1)\end{array}$ & $\begin{array}{l}\text { Tamaño de fuen- } \\
\text { te pequeño }\end{array}$ & $\begin{array}{l}\text { Sin elementos que } \\
\text { obstaculizan la visión } \\
\text { del gráfico. }\end{array}$ & $\begin{array}{l}\text { El gráfico se puede } \\
\text { redimensionar. }\end{array}$ & No & No \\
\hline 29 & $\begin{array}{l}\text { Contraste } \\
\text { suficiente (4,5:1 } \\
\text { o más) }\end{array}$ & $\begin{array}{l}\text { Contraste insufi- } \\
\text { ciente }(1,49: 1)\end{array}$ & $\begin{array}{l}\text { Tamaño de fuen- } \\
\text { te pequeño }\end{array}$ & $\begin{array}{l}\text { Sin elementos que } \\
\text { obstaculizan la visión } \\
\text { del gráfico. }\end{array}$ & $\begin{array}{l}\text { El gráfico se puede } \\
\text { redimensionar. }\end{array}$ & NA & NA \\
\hline 30 & $\begin{array}{l}\text { Contraste } \\
\text { suficiente (4,5:1 } \\
\text { o más) }\end{array}$ & $\begin{array}{l}\text { Contraste insufi- } \\
\text { ciente }(1,68: 1)\end{array}$ & $\begin{array}{l}\text { Tamaño de fuen- } \\
\text { te pequeño }\end{array}$ & $\begin{array}{l}\text { Sin elementos que } \\
\text { obstaculizan la visión } \\
\text { del gráfico. }\end{array}$ & $\begin{array}{l}\text { El gráfico se puede } \\
\text { redimensionar. }\end{array}$ & No & No \\
\hline 31 & $\begin{array}{l}\text { Contraste } \\
\text { suficiente (4,5:1 } \\
\text { o más) }\end{array}$ & $\begin{array}{l}\text { Contraste insufi- } \\
\text { ciente }(2,09: 1)\end{array}$ & $\begin{array}{l}\text { Tamaño de fuen- } \\
\text { te pequeño }\end{array}$ & $\begin{array}{l}\text { Sin elementos que } \\
\text { obstaculizan la visión } \\
\text { del gráfico. }\end{array}$ & $\begin{array}{l}\text { El gráfico se puede } \\
\text { redimensionar. }\end{array}$ & No & No \\
\hline 32 & $\begin{array}{l}\text { Contraste } \\
\text { suficiente }(4,5: 1 \\
\text { o más) }\end{array}$ & $\begin{array}{l}\text { Contraste insufi- } \\
\text { ciente }(1,7: 1)\end{array}$ & $\begin{array}{l}\text { Tamaño de fuen- } \\
\text { te pequeño }\end{array}$ & $\begin{array}{l}\text { Sin elementos que } \\
\text { obstaculizan la visión } \\
\text { del gráfico. }\end{array}$ & $\begin{array}{l}\text { El gráfico se puede } \\
\text { redimensionar. }\end{array}$ & No & No \\
\hline 33 & $\begin{array}{l}\text { Contraste } \\
\text { suficiente (4,5:1 } \\
\text { o más) }\end{array}$ & $\begin{array}{l}\text { Contraste sufi- } \\
\text { ciente (3:1 o más) }\end{array}$ & $\begin{array}{l}\text { Tamaño de fuen- } \\
\text { te pequeño }\end{array}$ & $\begin{array}{l}\text { Sin elementos que } \\
\text { obstaculizan la visión } \\
\text { del gráfico. }\end{array}$ & $\begin{array}{l}\text { El gráfico se puede } \\
\text { redimensionar, pero } \\
\text { se solapa con otros } \\
\text { elementos. }\end{array}$ & No & No \\
\hline 34 & $\begin{array}{l}\text { Contraste insufi- } \\
\text { ciente }(1,7: 1)\end{array}$ & $\begin{array}{l}\text { Contraste insufi- } \\
\text { ciente }(1,87: 1)\end{array}$ & $\begin{array}{l}\text { Tamaño de fuen- } \\
\text { te pequeño }\end{array}$ & $\begin{array}{l}\text { Sin elementos que } \\
\text { obstaculizan la visión } \\
\text { del gráfico. }\end{array}$ & $\begin{array}{l}\text { El gráfico se puede } \\
\text { redimensionar. }\end{array}$ & No & No \\
\hline 35 & $\begin{array}{l}\text { Contraste insufi- } \\
\text { ciente }(1,96: 1)\end{array}$ & $\begin{array}{l}\text { Contraste insufi- } \\
\text { ciente }(1,7: 1)\end{array}$ & $\begin{array}{l}\text { Tamaño de fuen- } \\
\text { te pequeño }\end{array}$ & $\begin{array}{l}\text { Sin elementos que } \\
\text { obstaculizan la visión } \\
\text { del gráfico. }\end{array}$ & $\begin{array}{l}\text { El gráfico se puede } \\
\text { redimensionar. }\end{array}$ & NA & NA \\
\hline
\end{tabular}

En general, no se observa un uso sistemático de paletas de colores seguras, sino que cada gráfico parece crearse siguiendo criterios estéticos y formales totalmente diferentes. Se echan en falta guías o manuales de estilo de uso generalizado en los medios de comunicación analizados, a pesar de saberse de la existencia de dichas guías para otros aspectos de la redacción. La única excepción en este sentido es el diario The guardian, en el cual sí que encontramos una cierta homogeneidad de colores y diseño.

Por lo que respecta al contraste, 26 gráficos presentan una ratio entre colores adyacentes inferior a la ratio exigida como novedad por las WCAG 2.1 en su nivel AA (3:1). Mientras que tan sólo en 6 gráficos se ha identificado un contraste entre texto y fondo inferior al requerido. Un requisito, este último, que ya constaba en las WCAG 1 y 2 . No obstante, en muchos casos, la ratio exigida de 4,5:1, se alcanza al límite, al utilizarse tonos de gris para el texto, en lugar de negro u otros colores con mayor contraste.

Si bien las WCAG no especifican una fuente o tamaño mínimo requerido para el texto, sino que se centran en permitir al usuario poder personalizar ambas, existe el consenso generalizado de considerar las fuentes sin serifa y los 12pt (o los 16px equivalentes) como un estándar para la lectura en pantalla (Nielsen, 2002). Estas recomendaciones tienen su origen y tenían sentido en un momento en el que se contaba con pantallas con una resolución muy inferior a las de las que se pueden encontrar hoy en el mercado (Nielsen, 2012). Trabajos como el de Bernard, Liao y Mills (2014) han comparado diferentes fuentes y tamaños en relación con su legibilidad y velocidad de lectura, pero no son suficientes para extraer conclusiones. Por lo que respecta a los gráficos que nos ocupan, si bien todos emplean fuentes sin serifa -a excepción de algunas fuentes con serifa observadas en unos pocos títulos-, 29 de los 35 gráficos presentan un tamaño de fuente para los ejes, etiquetas y pies inferior a los 16px. Además, como se ha comentado, el problema no radica tanto en el valor, como en el hecho de que la mayoría de los gráficos son imágenes en formato de mapa de bits (23 de 35), por lo que modificar las características del texto (tamaño, fuente, etc.), resulta imposible, algo que técnicamente es mucho más fácil de llevar a cabo sobre los gráficos en formato SVG analizados (12 de 35). En cuanto a los formatos de mapa de bits empleados, la gran mayoría de las imágenes son ficheros JPG (18 de 23), mientras que tan sólo 5 son imágenes en formato PNG. El formato PNG presenta un mejor rendimiento frente a JPEG en la compresión de imágenes formadas por grandes áreas de color uniformes. Por contra, JPEG a pesar de poder alcanzar tasas de compresión superiores, lo hace en 
detrimento de algunos detalles que pueden resultar en una calidad final inferior, así como en la aparición de "artefactos" en grandes áreas uniformes de color y texto.

El hecho de disponer de sitios web con diseños responsivos ${ }^{6}$ fomenta que las imágenes ampliadas con zoom ocupen el $100 \%$ de la pantalla con una visualización completa y sin elementos superpuestos. Incluso en webs que aplican diseños responsivos, en algunas ocasiones elementos como los menús de navegación fijos en la cabecera ocupan una parte importante de la interfaz e impiden ver el gráfico por completo. En este sentido, si bien todos los gráficos analizados se pudieron redimensionar hasta un $200 \%$ para aumentar su tamaño, en 7 casos la imagen no pre-

Varios medios nacionales mostraban banners publicitarios superpuestos a los gráficos dificultando o imposibilitando su lectura

sentaba la calidad suficiente para asegurar una correcta legibilidad por su baja resolución y tamaño iniciales, y en otros 7 casos se solapaba con otros elementos presentes en la página.

10 de los 35 gráficos mostraban banners publicitarios superpuestos dificultando o imposibilitando con su aparición la lectura del gráfico. En uno de los gráficos se incluía una marca de agua de autoría que imposibilitaba la lectura de parte del gráfico.

Por lo que respecta a las características y funciones adicionales, ninguno de los gráficos analizados en formato SVG era accesibles a través del teclado, imponiendo límites importantes a aquellos usuarios que usan esta interfaz en combinación con un lector de pantalla. En el mismo sentido, en la mayoría de los gráficos, los elementos que los componen (barras, líneas, etc.) tampoco eran capaces de recibir el foco del ratón o el teclado, ni estaban etiquetados convenientemente para que, una vez el usuario llega a ellos, pueda acceder a la información o el dato que representan.

Por lo que respecta a la personalización, los gráficos en formato de mapa de bits no cumplen con este requisito al tratarse de representaciones estáticas sobre las cuales difícilmente se pueden aplicar cambios en la tipografía, tamaño del texto, combinaciones de colores, etc. En el caso de los gráficos en formato SVG, estos sí presentan una mejor compatibilidad con ayudas técnicas o extensiones de navegador que facilitan a los usuarios el uso de hojas de estilo específicas adaptadas a sus necesidades y preferencias. Por otro lado, ninguno de los gráficos analizados cuenta con opciones de personalización propias como empieza a ser habitual en otros tipos de contenido.

\section{Discusión}

La mayoría de los gráficos analizados ( 25 de 35) utiliza imágenes en formato de mapa de bits para ser incorporados a las noticias. No obstante, algunos de estos medios han empezado a implementar -en el caso de los españoles, tímidamente-, tecnologías basadas en la Web que hacen posible la creación de gráficos dinámicos e interactivos en sustitución del software ofimático de hojas de cálculo o programas específicos de diseño que tradicionalmente se venía empleando. Este tipo de tecnologías abre las puertas a todo un nuevo conjunto de posibilidades que pueden mejorar la accesibilidad de los gráficos resultantes. En primer lugar, el hecho de tratarse de una imagen no estática favorece la inclusión de texto real en los gráficos (título, ejes, etiquetas, leyendas...), pudiendo convertirse este con facilidad a otros formatos o presentaciones. También admiten una buena compatibilidad con interfaces de teclado y lectores de pantalla, característica que beneficia a los usuarios con muy poco resto de visión o que utilizan estas ayudas técnicas en combinación con otras como los magnificadores de pantalla. El hecho de tratarse de elementos nativos del estándar HTML que se insertan en el

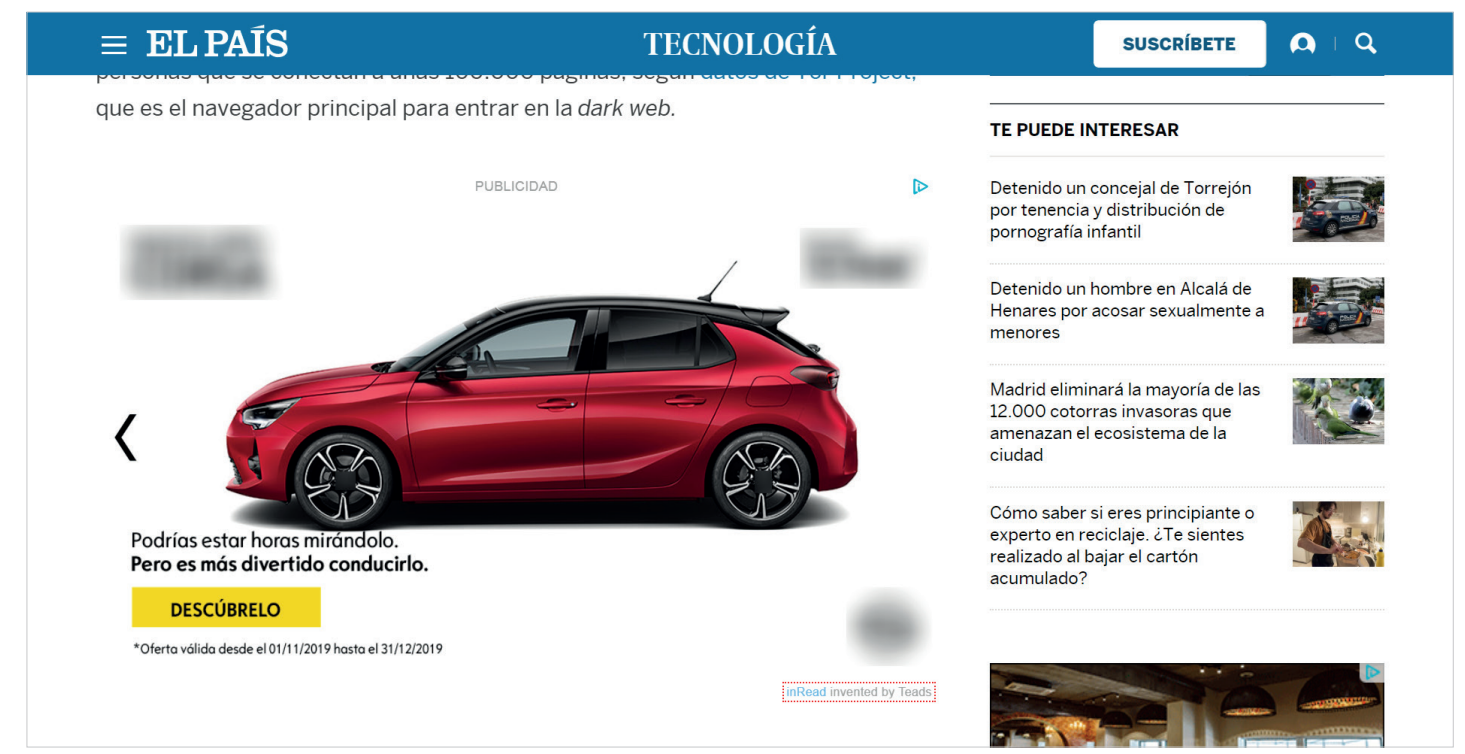

Figura 8. Banner publicitario superpuesto totalmente sobre un gráfico y que no ofrece mecanismos para ser cerrado. Fuente: El país. 
Modelo de Objetos del documento (en inglés, DOM), les confiere un alto grado de personalización, permitiendo su manipulación en vistas a ofrecer diferentes versiones de un mismo gráfico. La posibilidad de personalización es una característica de interés extremadamente útil vista la variabilidad existente entre el perfil de usuarios de baja visión. Esta funcionalidad puede venir dada por el creador del gráfico, ofreciendo una interfaz personalizable, o facilitarse a través de la implementación de estándares y tecnologías compatibles con terceras aplicaciones que sean capaces de acceder a las hojas de estilo de la página y modificar sus propiedades, posibilitando a cada usuario seleccionar combinaciones de colores, familias tipográficas o tamaños de texto, entre otros.

El resultado de las evaluaciones advierte que es tan importante la tecnología con la que se genera el contenido, como las políticas, criterios y buenas prácticas seguidas en su creación. Si cualquiera de los dos componentes falla, el contenido no será accesible. Las posibilidades que acabamos de comentar, aunque factibles, no se han observado en los gráficos dinámicos analizados, pareciendo centrarse más los medios analizados en la dimensión estética de este tipo de gráficos, que en su usabilidad y accesibilidad. Esto se pone de manifiesto en la prácticamente nula inclusión de alternativas de texto para las marcas de los gráficos a través de atributos WAI-ARIA, o en la incapacidad de las marcas para recibir el foco del teclado -en muchos incluso también del ratón o a través de interacciones táctiles-, por poner sólo un par de ejemplos.

Entre los resultados de esta investigación, destacan los problemas de accesibilidad no sólo para las personas con baja visión, sino para otros muchos perfiles de usuario, derivados de la ingente cantidad de publicidad intrusiva presente en una buena parte de los medios analizados. Este problema se manifiesta en forma de elementos que se superponen sobre la información principal de la página y que resultan complicados de cerrar, siendo en algunos casos imposible realizar esta acción hasta que el vídeo o animación no finaliza (figura 8). Los dos diarios internacionales analizados son los únicos que en ningún caso mostraron obstáculos publicitarios.

Otro aspecto que llama la atención es el pobre uso de pies en los gráficos analizados. Los pies de imagen se pueden usar para incluir información adicional de interés para ayudar al lector a comprender el mensaje que se intenta transmitir, ampliar la información con anotaciones adicionales, resumir cuestiones clave que interesa comunicar, además de ser el lugar idóneo en el cual proporcionar la fuente de los datos, las abreviaturas o las unidades de medida utilizadas (Splendiani, 2015). La importancia de este elemento para la compresión del gráfico ha sido demostrada en diversos trabajos (Elzer et al., 2007) (Agarwal; Yu, 2009) (Yu et al., 2009) y cobran especial importancia en los documentos científicos, al incluir, en muchas ocasiones, información acerca de los resultados y conclusiones más importantes de la investigación a la que se refieren (Cohen; Wang; Murphy, 2003). Un elemento totalmente desaprovechado en los medios analizados.

\section{Conclusiones y trabajo futuro}

La evaluación heurística ha permitido detectar un importante número de problemas de accesibilidad, todos ellas recogidos en los resultados de este trabajo. El experimento con estos gráficos ha servido también para validar el conjunto de indicadores propuestos, así como para mejorar diferentes aspectos relacionados con ellos. El primero es la incorporación del indicador H15 (Sin obstáculos en la visualización) a la lista a petición de los evaluadores al detectar la existencia de banners publicitarios o marcas de agua que impedían percibir correctamente la información mostrada en los gráficos analizados. Otro aspecto que se revisó es la definición de cada indicador, a la cual se añadió una lista de verificación relacionada para facilitar a los evaluadores la compresión de cada uno. Tanto las nuevas definiciones, como la lista de verificación ya se contemplan en la tabla 3 de este trabajo. En la misma línea, los evaluadores recomendaron también incluir ejemplos de buenas y malas prácticas, así como ejemplos concretos de puntuación para facilitar aún más el proceso. Finalmente, queda pendiente también como trabajo futuro la revisión del indicador H17 (Navegación independiente del dispositivo), un indicador sólo aplicable a los gráficos en formatos diferentes a las imágenes ráster y que ninguno de los gráficos analizados cumplía.

Las heurísticas son una técnica de evaluación en la que no se necesitan usuarios para obtener resultados y tienen un gran reconocimiento en usabilidad, como demuestran los numerosos ejemplos existentes en la bibliografía científica. Este tipo de evaluaciones ayudan a descubrir aquellos aspectos de una interfaz que presentan problemas de usabilidad o accesibilidad de una manera efectiva, ágil y con un coste mínimo, en comparación de otras técnicas de evaluación, proporcionando además información sobre su solución (Paddison; Englefield, 2004). En este sentido, para que la lista de heurísticas sea realmente útil, se hace totalmente necesario un proceso de validación Los resultados constatan la falta de conocimiento y aplicación de buenas prácticas de accesibilidad en la creación de gráficos estadísticos en la prensa digital consideramos necesario seguir una metodología de diseño centrado en el usuario incorporando en una futura fase una muestra de usuarios representativa de los diferentes perfiles de baja visión, con el objetivo de verificar que los indicadores propuestos cubren todos los problemas asociados al dominio y acercarlos al usuario final. 
En este trabajo se ha constatado la falta de conocimiento y aplicación de buenas prácticas de accesibilidad en la creación de gráficos estadísticos en la prensa digital. Como aportación principal se ha validado una lista de indicadores heurísticos y el método asociado que complementa y concreta directrices más generales como las WCAG para los usuarios con baja visión o VCD, pensada no sólo para la evaluación de la accesibilidad los gráficos estadísticos, sino también como embrión de una futura guía de estilo o ejemplos con los paquetes informáticos más comunes que ayude a los autores, con independencia de sus conocimientos sobre accesibilidad digital, a crear gráficos estadísticos accesibles siguiendo unas pautas que faciliten su incorporación a la Web.

\section{Notas}

1. Según datos de octubre de 2019.

https://www.alexa.com/topsites/category/Top/News

\section{2. https://accessgarage.wordpress.com}

3. https://webaim.org/resources/contrastchecker

4. https://mediaarea.net/es/Medialnfo

5. https://www.nvaccess.org/download

6. El diseño web responsivo (responsive web design) es una técnica de diseño y desarrollo de sitios web que permite adaptar sus contenidos a las características y diferentes tamaños de pantalla de los diversos tipos de dispositivos desde los cuales se puede realizar la consulta (ordenadores de escritorio con diferentes tamaños de pantalla, tabletas, móviles, televisiones inteligentes, etc.)

\section{Referencias}

Agarwal, Shashank; Yu, Hong (2009). "FigSum: automatically generating structured text summaries for figures in biomedical literature". In: Proceedings of the 2009 Anual symposium of the American Medical Information Association (AMIA), pp. 6-10.

https://www.ncbi.nlm.nih.gov/pmc/articles/PMC2815407

Alcaraz-Martínez, Rubén; Ribera-Turró, Mireia; Granollers Saltiveri, Toni (2020). "La accesibilidad de los gráficos estadísticos para personas con baja visión y visión cromática deficiente: revisión de alcance y perspectivas". Interacción: revista digital de AIPO, n. 1.

http://revista.aipo.es/index.php/INTERACCION/article/view/9

Asociación para la Investigación de Medios de Comunicación (2019). Ranking de diarios, segunda ola 2019. http://reporting.aimc.es/index.html\#/main/diarios

Bernard, Michael; Liao, Chia-Hui; Mills, Melissa (2001). "The effects of font type and size on the legibility and reading time of online text by older adults". In: CHI EA'01: extended abstracts on human factors in computing systems, pp. 175176.

https://doi.org/10.1145/634067.634173

Bonastre, Laia; Granollers, Toni (2014). "A set of heuristics for user experience evaluation in e-commerce websites". In: ACHI 2014: the Seventh International Conference on Advances in Computer-Human Interactions, pp. 27-34. ISBN: 9781 612083254

Boudreau, Denis (2019). "Supporting the design phase with accessibility heuristics evaluations". Accessible user experience \& design.

https://www.deque.com/blog/supporting-the-design-phase-with-accessibility-heuristics-evaluations

Bourne, Rupert R. A. (2017). “Magnitude, temporal trends, and projections of the global prevalence of blindness and distance and near vision impairment: a systematic review and meta-analysis". Lancet global health, v. 5, pp. 888-897. https://doi.org/10.1016/S2214-109X(17)30293-0

Cabañero-Resta, Ángel-Andrés; Luján-Mora, Sergio (2012). Estudio sobre la accesibilidad de los sitios web de medios de comunicación. Alicante: Departamento de Lenguajes y Sistemas Informáticos de la Universidad de Alicante. http://hdl.handle.net/10045/20343

Cairo, Alberto (2017). "Visualización de datos: una imagen puede valer más que mil números, pero no siempre más que mil palabras". El profesional de la información, v. 26, n. 6, pp. 1025-1028.

https://doi.org/10.3145/epi.2017.nov.02

Cohen, William W.; Wang, Richard; Murphy, Robert F. (2003). “Understanding captions in biomedical publications”. In: Proceedings of the ninth ACM SIGKDD International Conference on Knowledge Discovery and Data Mining, pp. $499-504$. https://doi.org/10.1145/956750.956809 
Discapnet (2007). Accesibilidad en los diarios digitales españoles. Madrid: Discapnet. https://www.discapnet.es/sites/default/files/areas-tematicas/tecnologia/informedetalladoaccprensa.pdf

Discapnet (2016). Accesibilidad de los principales medios digitales de comunicación. Madrid: Discapnet. https://www.discapnet.es/areas-tematicas/tecnologiainclusiva/observatorio-de-accesibilidad-tic/informes-discapnet-0

Elzer, Stephanie; Carberry; Sandra, Chester, Daniel; Demir, Seniz; Green, Nancy; Zukerman, Ingrid; Trnka, Keith (2007). "Exploring and exploiting the limited utility of captions in recognizing intention in information graphics". In: Proceedings of the $43^{\text {rd }}$ Annual Meeting of the Association for Computational Linguistics (ACL'05), pp. 223-230. https://doi.org/10.3115/1219840.1219868

España (2014). "Real decreto 126/2014, de 28 de febrero, por el que se establece el currículo básico de la Educación Primaria". Boletín oficial del Estado, n. 52 (1 de marzo).

https://www.boe.es/eli/es/rd/2014/02/28/126/con

España (2015). “Real decreto 1105/2014, de 26 de diciembre, por el que se establece el currículo básico de la Educación Secundaria Obligatoria y del Bachillerato". Boletín oficial del Estado, n. 3 (3 de enero).

https://www.boe.es/eli/es/rd/2014/12/26/1105/con

Evergreen, Stephanie; Emery, Ann (2018) "Data visualization checklist". In: Presenting data effectively. Thousand Oaks, California: SAGE. ISBN: 9781506353128

Ferraz, Reinaldo (2017). "Accessibility and search engine optimization on scalable vector graphics". In: $4^{\text {th }}$ IEEE International Conference on Soft Computing and Machine Intelligence, pp. 94-98.

https://doi.org/10.1109/ISCMI.2017.8279605

Franklin, Fernanda; Breyer, Felipe; Kelner, Judith (2014). "Heurísticas de usabilidade para sistemas colaborativos remotos de realidade aumentada". In: Proceedings of XVI Symposium on Virtual and Augmented Reality, pp. 53-62.

González, María-Paula; Pascual, Afra; Lorés, Jesús (2001). “Evaluación heurística”. En: Introducción a la Interacción Persona-Ordenador. AIPO, Asociación Interacción Persona-Ordenador.

https://aipo.es/libro/pdf/15-Evaluacion-Heuristica.pdf

González-Perea, Lourdes (2018). "La accesibilidad de los medios de comunicación digitales en España: responsabilidad de los periodistas en la generación de contenidos inclusivos". Index.comunicación, v. 8, n. 1, pp. 225-253.

http://hdl.handle.net/10115/15759

Gutiérrez-Restrepo, Mary-Luz-Emmanuelle (2017). Accesibilidad no intrusiva en la comunicación audiovisual en la web. Tesis de doctorado, Universidad Complutense de Madrid, Facultad de Ciencias de la Información.

https://eprints.ucm.es/42257

Hermawati, Setia; Lawson, Glyn (2015). "A user-centric methodology to establish usability heuristics for specific domains". In: Proccedings of the International Conference on Ergonomics \& Human Factors, pp. 80-85.

https://doi.org/10.1201/b18293

Hermawati, Setia; Lawson, Glyn (2016). "Establishing usability heuristics for heuristics evaluation in a specific domain: is there a consensus?". Applied ergonomics, v. 56, pp. 34-51.

https://doi.org/10.1016/j.apergo.2015.11.016

Hub, Miloslav; Čapková, Věra (2010). "Heuristic evaluation of usability of public administration portal”. In: Proceedings of the International Conference on Applied Computer Science, pp. 234-239.

IBSA (2011) “IBSA medical classification". In: International Blind Sports Federation.

https://web.archive.org/web/20110811060928/http://www.ibsa.es/docinteres/HTM/MedicalClassification.htm

Inostroza, Rodolfo; Rusu, Cristian; Roncagliolo, Silvana; Rusu, Virginica (2013). "Usability heuristics for touchscreen-based mobile devices: update". In: Proceedings of the 2013 Chilean Conference on Human-Computer Interaction, pp. $24-29$. https://doi.org/10.1145/2535597.2535602

Jiménez, Cristhy; Allende-Cid, Hector; Figueroa, Ismael (2017). “Prometheus: PROcedural METhodology for developing HEuristics of Usability". IEEE Latin America transactions, v. 15, n. 3, pp. 541-549.

https://doi.org/10.1109/TLA.2017.7867606

Joyce, Ger; Lilley, Mariana (2014). "Towards the development of usability heuristics for native smartphone mobile applications". In: Third International Conference, DUXU 2014 Held as Part of HCl International 2014. Design, user experience, and usability theories, methods, and tools for designing the user experience, pp. 465-474.

https://doi.org/10.1007/978-3-319-07668-3_45

Koivunen, Marja-Riitta; McCathieNevile, Charles (2001). Accessible graphics and multimedia on the Web. World Wide Web Consortium (W3C)/MIT.

https://www.w3.org/2001/05/hfweb/heuristics.htm 
Lechner, Bettina; Fruhling, Ann; Petter, Stacie; Siy, Harvey (2013). "The chicken and the pig: user involvement in developing usability heuristics". In: $19^{\text {th }}$ Americas Conference on Information Systems, AMCIS 2013 - Hyperconnected World: Anything, Anywhere, Anytime, pp. 3263-3270. ISBN: 9781629933948

Legge, Gordon E. (2016). "Reading digital with low vision". Visible language, v. 50, n. 2, pp. 102-125. https://www.ncbi.n/m.nih.gov/pmc/articles/PMC5726769

Mankoff, Jennifer; Dey, Anind K.; Hsieh, Gary; Kientz, Julie, Lederer, Scott; Ames, Morgan (2003). "Heuristic evaluation of ambient displays". In: Proceedings of the SIGCHI conference on human factors in computing systems, pp. 169-176. https://doi.org/10.1145/642611.642642

Masip, Llúcia; Oliva, Marta; Granollers, Toni (2012). “The open repository of heuristics". In: Proceedings of the $13^{\text {th }}$ International Conference on Human-Computer Interaction, pp. 1-2.

http://doi.acm.org/10.1145/2379636.2379640

Meeks, Elijah; Cesal, Amy; Pettit, Mollie (2019). "Introducing the Data Visualization Society". Medium. https://medium.com/datavisualization-society/introducing-the-data-visualization-society-d13d42abObec

Mi, Na; Cavuoto, Lora A.; Benson, Kenneth; Smith-Jackson, Tonya; Nussbaum, Maury A. (2014). "Heuristic checklist for an accessible smartphone interface design". Universal access in information society, v. 13, n. 4, pp. 351-365. https://doi.org/10.1007/s10209-013-0321-4

Miqueli-Rodríguez, Maritza; López-Hernández, Silvia M.; Rodríguez-Masó, Susana (2016). “Baja visión y envejecimiento de la población". Revista cubana de oftalmología, v. 29, n. 3.

http://ref.scielo.org/7sm8wq

Naciones Unidas. Departamento de Asuntos Económicos y Sociales. División de Población (2017). World population prospects 2017 data booklet.

https://population.un.org/wpp/Publications/Files/WPP2017_DataBooklet.pdf

Nielsen, Jakob (1992). "Finding usability problems through heuristic evaluation". In: Proceedings ACM CHI'92 Conference, pp. 373-380.

https://doi.org/10.1145/142750.142834

Nielsen, Jakob (1994). "How to conduct a heuristic evaluation". Nielsen Norman Group.

https://www.nngroup.com/articles/how-to-conduct-a-heuristic-evaluation

Nielsen, Jakob (2002). "Let users control font size". Nielsen Norman Group. Blog.

https://www.nngroup.com/articles/let-users-control-font-size

Nielsen, Jakob (2012). "Serif vs. sans-serif fonts for HD screens". Nielsen Norman Group. Blog.

https://www.nngroup.com/articles/serif-vs-sans-serif-fonts-hd-screens

Nielsen, Jakob; Landauer, Thomas K. (1993). "A mathematical model of the finding of usability problems". In: Proceedings ACM/IFIP INTERCHI'93 Conference, pp. 206-213.

https://doi.org/10.1145/169059.169166

Nielsen, Jakob; Molich, Rolf (1990). "Heuristic evaluation of user interfaces". In: CHI '90: proceedings of the SIGCHI Conference on Human Factors in Computing Systems, pp. 249-256.

https://doi.org/10.1145/97243.97281

Paddison Claire; Englefield Paul (2004). "Applying heuristics to accessibility inspections". Interacting with computers, v. 16, n. 3, pp. 507-521.

https://doi.org/10.1016/j.intcom.2004.04.007

Parra-Valcarce, David (2010). “La accesibilidad web en los cibermedios del Grupo Planeta a ambos lados del Atlántico: los casos de La Razón y El Tiempo". Naveg@mérica: revista electrónica de la Asociación Española de Americanistas, n. 4, pp. 1-13.

https://revistas.um.es/navegamerica/article/view/99961

Parra-Valcarce, David; Martínez-Arias, Santiago (2018). Tecnologías de la gestión periodística de la información digital: conceptos básicos. Madrid: Los Autores. ISBN: 9788409039821

Quiñones, Daniela; Rusu, Cristian; Rusu, Virginica (2018). “A methodology to develop usability/user experience heuristics". Computer standards \& interfaces, v. 59, n. C, pp. 109-129.

https://doi.org/10.1016/j.csi.2018.03.002

Roa-Amaya, Matilde; Caldera-Serrano, Jorge (2011). “Evaluación heurística de las sedes web de los medios digitales: El País y El Mundo". Cuadernos de documentación multimedia, v. 22, pp. 28-150.

https://doi.org/10.5209/rev_CDMU.2011.v22.38340 
Rusu, Cristian; Roncagliolo, Silvana; Rusu, Virginica; Collazos, César A. (2011). "A methodology to establish usability heuristics". In: Proceedings of the Fourth International Conference on Advances in Computer-Human Interactions, ACHI2011, pp. 59-62. ISBN: 9781612081175

Snellen, Herman (1862). Probebuchstaben zur Bestimmung der Sehschärfe, Utrecht: Van de Weijer.

Splendiani, Bruno (2015). A proposal for the inclusion of accessibility criteria in the authoring workflow of images for scientific articles. Tesis de doctorado, Universitat de Barcelona, Facultat de Biblioteconomia i Documentació.

http://hdl.handle.net/10803/386242

Szpiro, Sarit-Felicia-Anais; Hashash, Shafeka; Zhao, Yuhang; Azenkot, Shiri (2016). "How people with low vision access computing devices: understanding challenges and opportunities". In: ASSETS '16 Proceedings of the $18^{\text {th }}$ International ACM SIGACCESS Conference on Computers and Accessibility, pp. 171-180.

https://dl.acm.org/doi/10.1145/2982142.2982168

Utray-Delgado, Francisco (2009). Accesibilidad a la TDT en España para personas con discapacidad sensorial (20052007). Madrid: Real Patronato sobre Discapacidad.

http://riberdis.cedd.net/handle/11181/2873

Van-Greunen, Darelle; Yeratziotis, Alexandros; Pottas, Dalenca (2011). "A three-phase process to develop heuristics". In: Proceedings of the $13^{\text {th }}$ Anual Conference on World Wide Web Applications, Johannesburg, pp. 5-23.

WebAIM (2013). Survey of users with low vision results.

https://webaim.org/projects/lowvisionsurvey

Wetzlinger, Werner; Auinger, Andreas; Dörflinger, Michael (2014). “Comparing effectiveness, efficiency, ease of use, usability and user experience when using tablets and laptops". In: Third International Conference, DUXU 2014 Held as Part of HCl International 2014. Design, user experience, and usability theories, methods, and tools for designing the user experience, pp. 402-412.

https://doi.org/10.1007/978-3-319-07668-3_39

World Wide Web Consortium (2017). Accessible rich internet applications (WAI-ARIA) 1.1.

https://www.w3.org/TR/wai-aria

World Wide Web Consortium (2018a). Web content accessibility guidelines (WCAG) 2.1. W3C.

https://www.w3.org/TR/WCAG21

World Wide Web Consortium (2018b). WAI-ARIA graphics module.

https://www.w3.org/TR/graphics-aria-1.0

World Health Organization (2019). "Ceguera y discapacidad visual". En: Notas descriptivas.

https://www.who.int/es/news-room/fact-sheets/detail/blindness-and-visual-impairment

Yu, Hong; Agarwal, Shashank; Johnston, Mark; Cohen, Aaron (2009). "Are figure legends sufficient? evaluating the contribution of associated text to biomedical figure comprehension". Journal of biomedical discovery and collaboration, v. 4 , n. 1.

https://doi.org/10.1186/1747-5333-4-1

Anexo 1. Heurísticas de control

\begin{tabular}{|l|c|}
\hline \multicolumn{1}{|c|}{ Criterio de conformidad } & Nivel de conformidad \\
\hline 1.1.1. Non-text content & $\mathrm{A}$ \\
\hline 1.3.3. Sensory characteristics & $\mathrm{A}$ \\
\hline 1.4.1. Use of color & $\mathrm{A}$ \\
\hline 1.4.3. Contrast (minimum) & $\mathrm{A}$ \\
\hline 1.4.4. Resize text & $\mathrm{AA}$ \\
\hline 1.4.5. Images of text & $\mathrm{AA}$ \\
\hline 1.4.11. Non-text contrast & $\mathrm{AA}$ \\
\hline 1.4.12. Text spacing & $\mathrm{AA}$ \\
\hline 2.1.1. Keyboard & $\mathrm{A}$ \\
\hline 2.1.2. No keyboard trap & $\mathrm{A}$ \\
\hline 2.4.3. Focus order & $\mathrm{A}$ \\
\hline 2.4.6. Headings and labels & $\mathrm{AA}$ \\
\hline 2.4.7. Focus visible & $\mathrm{AA}$ \\
\hline 2.5.1. Pointer gestures & $\mathrm{A}$ \\
\hline
\end{tabular}




\section{Anexo 2. URLs de los gráficos analizados}

\begin{tabular}{|c|c|}
\hline ID & URL \\
\hline 1 & https://elpais.com/elpais/2019/09/27/ciencia/1569574792_048614.html \\
\hline 2 & https://elpais.com/tecnologia/2019/09/26/actualidad/1569509603_511250.html \\
\hline 3 & https://elpais.com/sociedad/2019/09/25/actualidad/1569402395_914747.html \\
\hline 4 & https://elpais.com/politica/2019/09/13/actualidad/1568392009_467154.html \\
\hline 5 & https://elpais.com/tecnologia/2019/09/24/actualidad/1569332904_298329.html \\
\hline 6 & https://www.elmundo.es/economia/2019/10/04/5d963e4421efa0a16a8b4604.html \\
\hline 7 & https://www.elmundo.es/pais-vasco/2019/09/30/5d91c052fc6c83db238b4672.html \\
\hline 8 & https://www.elmundo.es/ciencia-y-salud/ciencia/2019/09/25/5d8a4183fdddff25b18b46d0.html \\
\hline 9 & https://www.elmundo.es/television/2019/09/18/5d8271a3fdddffb2798b45ae.html \\
\hline 10 & https://www.elmundo.es/economia/macroeconomia/2019/10/02/5d944bc7fc6c83c26d8b4630.html \\
\hline 11 & https://www.lavanguardia.com/internacional/20191005/47804274949/elecciones-portugal-antonio-costa-sondeos.html \\
\hline 12 & ttps://www.lavanguardia.com/economia/20191004/47793185853/aranceles-eeuu-espana-impacto-productos-millones.html \\
\hline 13 & https://www.lavanguardia.com/servicios/bolsa/index.html \\
\hline 14 & https://www.lavanguardia.com/tecnologia/20190530/462567641011/napster-20-aniversario-musica-gratis.html \\
\hline 15 & https://www.lavanguardia.com/natural/cambio-climatico/20191010/47886089658/mediterraneo-crisis-climatica-mosquitos-agua.html \\
\hline 16 & https://www.abc.es/economia/abci-empleo-crece-menor-ritmo-desde-2014-y-confirma-desaceleracion-201910020859_noticia.html \\
\hline 17 & https://www.abc.es/economia/abci-gobierno-prepara-subida-2-por-ciento-sueldo-empleados-publicos-201910082059_noticia.html \\
\hline 18 & $\begin{array}{l}\text { https://www.abc.es/espana/madrid/abci-ayuntamiento-madrid-reordenara-trafico-plaza-eliptica-para-reducir-contamina- } \\
\text { cion-201910082002_noticia.html }\end{array}$ \\
\hline 19 & https://www.abc.es/sociedad/abci-espanoles-aceptan-mejor-eutanasia-aborto-201910091110_noticia.html \\
\hline 20 & https://www.abc.es/economia/abci-comprueba-si-vives-encima-o-debajo-renta-media-localidad-201910021046_noticia.html \\
\hline 21 & https://www.elperiodico.com/es/politica/20191006/encuesta-sentencia-proces-7668336 \\
\hline 22 & https://www.elperiodico.com/es/politica/20191005/sondeo-espana-gobierno-investidura-7667832 \\
\hline 23 & https://www.elperiodico.com/es/politica/20191007/encuestas-elecciones-generales-2019-sondeos-7648130 \\
\hline 24 & https://www.elperiodico.com/es/politica/20191005/encuesta-elecciones-generales-2019-espana-7668120 \\
\hline 25 & https://www.elperiodico.com/es/politica/20191010/encuesta-autonomicas-comunidad-valenciana-7675510 \\
\hline 26 & https://www.nytimes.com/2019/10/02/business/economy/markets-world-trade.html \\
\hline 27 & https://www.nytimes.com/2019/09/30/upshot/democrats-2020-losing-independents.html \\
\hline 28 & https://www.nytimes.com/2019/10/03/health/sutter-hospitals-medical-bills.html \\
\hline 29 & https://www.nytimes.com/2019/10/09/us/politics/elizabeth-warren-fundraising.html \\
\hline 30 & https://www.nytimes.com/2019/10/04/business/economy/jobs-report.html \\
\hline 31 & https://www.theguardian.com/politics/2019/oct/08/no-deal-brexit-would-push-national-debt-to-levels-last-seen-in-60s \\
\hline 32 & https://www.theguardian.com/environment/2019/oct/09/revealed-20-firms-third-carbon-emissions \\
\hline 33 & https://www.theguardian.com/environment/ng-interactive/2019/oct/09/half-century-dither-denial-climate-crisis-timeline \\
\hline 34 & https://www.theguardian.com/business/2019/oct/10/uk-looks-likely-to-avoid-recession-despite-brexit-chaos \\
\hline 35 & https://www.theguardian.com/environment/2019/oct/10/oil-firms-barrels-markets \\
\hline
\end{tabular}

Profesional de la -información http://www.elprofesionaldelainformacion.com

e-ISSN: 1699-2407 https://doi.org/10.3145/EPI

Revista internacional de

Información y Comunicación

indexada por WoS Social Sciences Citation Index (Q2)

Scopus (Q1) y otras bases de datos
Bienvenido a EP| Revista cientifica internacional

Factor de impacto JCR:

JIF $2019=1,580$

Scopus/SCImago Journal Rank:

SJR $2019=0,480$ 